\title{
Manichaean Christians in Augustine's Life and Work
}

\author{
Johannes van Oort
}

\begin{abstract}
The article aims to give an overall overview of St Augustine's attitude towards the GnosticChristian Manichaeans. First, a historical overview, mainly based on his Confessions, outlines Augustine's acquaintance with the members of the Manichaean Church and his familiarity with their writings. Second, the place of the Manichaeans in a considerable number of Augustine's other works is discussed. It is in particular in his many anti-Manichaean writings that the Church Father displays his intimate knowledge of the Manichaeans' myth and their doctrines. Third, a summary is given of the research on the impact of the Manichaeans on Augustine. It is concluded that, from his early years onwards and to the very end of his life, the Manichaean Christians were a real and powerful force to him.
\end{abstract}

\section{Keywords}

Augustine of Hippo; Manichaeism; Patristics; Gnosticism; Roman Africa; history of Christian doctrine

\section{Introduction}

In Augustine's life and work, the Manichaeans played a major role. They entered the course of his life when he was a young student of eighteen years, and their presence is perceptible even in his very final writings. Nearly all of his works deal with Manichaean questions, but in several of his books the Manichaeans and their doctrines are at the very centre of the discussion.

In comparison with, for instance, Augustine's attitude towards the Donatists and the Pelagians, his relation with the Manichaeans is far less studied. Whereas every biographer of Augustine will try to read texts of the Neoplatonists, the Donatists, or the so-called Pelagians in order to understand their importance to his subject, many of them failed to do so in regard to the Manichaean writings. Distinguished scholars of Augustine still author books and other 
studies without any specific knowledge of the alternative Christian Church to which the future Catholic Christian church father adhered for more than a decade, and whose sacred texts he studied ardently.

These circumstances have a certain bearing on the present study. ${ }^{1}$ The fact that the significance of the Manichaeans in Augustine's life and work is still underestimated in scholarly circles brings about the situation that even an article intended to provide an overall overview of the topic has to break much new ground. This seems to be all the more necessary, because in recent times several new documents of the Manichaeans have been discovered, many of which are relevant to our knowledge of their existence in the Roman Empire, and thus to our understanding of Augustine as well. ${ }^{2}$ Where necessary, the importance of such new documents will be indicated. I will also indicate the evident place of the Manichaeans in a number of writings of Augustine, though in this overview there is no room for a thorough investigation of their significance in all cases. The same goes for the different influences of the Manichaeans on Augustine. Here, an immense field is still awaiting to be explored, and newly discovered sources of the Manichaeans, in conjunction with fresh (oftentimes even very first) editions of earlier discovered material, seem to offer exciting opportunities.

This study is structured as follows. First, a historical overview outlines Augustine's acquaintance with the Manichaeans and his familiarity with their writings. Second, the place of the Manichaeans in a number of Augustine's works is discussed. It is in particular here that his intimate knowledge of the Manichaeans' myth and their doctrines will become apparent. Third, a brief summary is given of the research on the influences of the Manichaeans on Augustine. Except for the final section, our main references are to original texts rather than scholarly studies. ${ }^{3}$

1) Titles of biblical and other ancient texts are abbreviated in accordance with common practice; the writings of Augustine in accordance with the Augustinus-Lexikon, (Basel I986 ff). Further, in the notes, A. = Augustine; CFM = Corpus Fontium Manichaeorum; M. = Manichaeans; NHMS = Nag Hammadi and Manichaean Studies.

2) An excellent bibliographical overview of all studies and text editions relating to the $M$. is provided by Gunner Mikkelsen, Bibliographica Manichaica. A Comprehensive Bibliography of Manichaeism through I996 (CFM, Subsidia I), (Turnhout I997). Mikkelsen has listed all main studies relevant to A. as well. Later publications, both on the M. and A.'s relation to them, are yearly listed in the Manichaean Studies Newsletter published by Brepols (Turnhout).

3) Until now, the topic has been particularly studied in the French speaking world, first in the excellent monograph by Prosper Alfaric, L'Évolution intellectuelle de saint Augustin, 


\section{Augustine's Acquaintance with the Manichaeans and Their Writings}

The Manichaeans entered Augustine's life in his nineteenth year, i.e. somewhere between I 3 Nov. 372 and I 3 Nov. 373. His main account of the event is given in the Confessions, Book 3,6, Io (with further reflection in the following paragraphs). Augustine begins by tellling that he "fell in" with people who professed a kind of trinitarian Christian doctrine and claimed to make known "the truth." 4

Apart from a number of fulminations against his former fellow believers, Augustine's account is full of noteworthy details. Firstly, the Manichaeans held some sort of trinitarian doctrine. The same is indicated in the so-called Capitula of Faustus 5 and, among many other texts, in the Coptic Manichaean Psalm-Book:6 "Glory, victory to the Father, the God of Truth; and his beloved son Christ; and the Holy Spirit, the Paraclete."7 Secondly, the Manichaeans

I: Du Manichéisme au Néoplatonisme, (Paris 1918), and later on by François Decret in a number of groundbraking publications: Aspects du manichéisme dans l'Afrique romaine. Les controverses de Fortunatus, Faustus et Felix avec saint Augustin, (Paris 1970); L'Afrique manichéenne (IVe-Ve siècles). Étude historique et doctrinale, I: Texte, II: Notes, (Paris I978); Essais sur l'Église manichéenne en Afrique du Nord et à Rome au temps de Saint Augustin. Recueil d'etudes, (Roma 1995). Though highly valuable as pioneering works, the books of Decret rather often lack in precison and clear structure. The recent book by Jason David BeDuhn, Augustine's Manichaean Dilemma, I: Conversion and Apostasy, 373-388 C.E., (Philadelphia 2010), may be welcomed as a highly readable and trustworthy guide for an English speaking audience, being the first volume of a projected "three-volume examination of Augustine's career-spanning engagement with Manichaeism." Apart from Alfaric, there will be no further references to these comprehensive studies. The present article, apart from being based on a fresh reading of the original sources, tries to explore new avenues mainly in the light of newly discovered Manichaean texts and a number of recent specialist studies.

4) Conf. 3,6, Io: "Itaque incidi in homines superbe delirantes, carnales nimis et loquaces, in quorum ore laquei diaboli et uiscum confectum commixtione syllabarum nominis tui et domini Iesu Christi et paracleti consolatoris nostri spiritus sancti. Haec nomina non recedebant de ore eorum, sed tenus sono et strepitu linguae; ceterum cor inane ueri. Et dicebant: "Veritas et ueritas' et multum eam dicebant mihi ...."

5) Faustus in c. Faust. 20,2: "Igitur nos patris quidem dei omnipotentis et Christi filii eius et spiritus sancti unum idemque sub triplici appellatione colimus numen."

6) Coptic Manichaean texts such as a Psalm-Book, Homilies, and Kephalaia (or "Chapters," some sort of dogmatical work in the form of Questions and Answers, i.e. antique erotapokriseis-literature) were discovered in Medinet Madi in Egypt in the late I920s. Editions (and translations) are indicated in the following notes.

7) C.R.C. Allberry (ed., tr.), A Manichaean Psalm-Book, Part II, (Stuttgart 1934), 49,29- 
professed the name of the Lord Jesus Christ. Close reading of Augustine's oeuvre reveals that, whenever he mentions the Manichaeans, he regards them as Christians. This Christ-centered character of Manichaeism is evidenced by Latin texts such as Faustus's so-called Capitula, Secundinus's Epistula and the Fragmenta Tabestina $;^{8}$ by the Greek Cologne Mani Codex ${ }^{9}$ and other texts from Egypt such as the many psalms to Jesus or Christ in the Coptic Psalm-Book. ${ }^{10}$ Besides, it is even present in the Central and East Asian texts and artefacts from Turfan, Tun-huang, and elsewhere. ${ }^{11}$ Likewise, Augustine's record of the Manichaeans as speaking of "ueritas et ueritas" is confirmed by many sources

30. Cf., e.g., 82,30-3I; I I3,I8-I9; I64,I4; and I90,25: "the Father, the Son, the holy Spirit." Other texts in Eugen Rose, Die manichäische Christologie, (Wiesbaden I979), I 58 I6I. It is remarkable that neither in his debate with Felix (c. Fel. I, I6) nor in c. Fort. 3 A. is criticizing the Manichaean trinitarian doctrine. Cf., e.g., c. ep. Man. 7,8 and I I , I 2 .

8) A codex with fragments of a Manichaean writing (or writings?) was discovered in a cave near Algerian Tébessa in I918. Its contents deal with Manichaean biblical exegesis, mainly of texts from the Gospels and from the Pauline letters. It is still discussed whether the codex provides original work of Mani in translation, or a Latin translation of some other Manichaean work(s), or possibly a writing (or writings) authored by some Latin speaking Manichaean(s). Latest edition with commentary by Markus Stein, Manichaica Latina. Band 3,I/2: Codex Thevestinus (Papyrologica Coloniensia 27/3,I/2), (Paderborn 2004).

9) The Cologne Mani Codex or Codex Manichaicus Coloniensis (CMC) is a Greek parchment codex discovered in Egypt at the end of the sixties of the previous century. The $C M C$ provides the original accounts of Mani's first disciples about Mani's youth and first missionary journeys. Best editions: Albert Henrichs \& Ludwig Koenen (ed., tr.), 'Ein griechischer Mani-Codex (P. Colon. inv. nr. 4780), Zeitschrift für Papyrologie und Epigraphik 5 (I970) 97-2 I 6; Ludwig Koenen \& Cornelia Römer (ed., tr.), Der Kölner Mani-Kodex, (Opladen I988); Cornelia Eva Römer (ed., tr.), Manis frühe Missionsreisen nach der Kölner Manibiographie, (Opladen I994).

10) Allberry, Manichaean Psalm-Book, e.g., 49-97; I I6-I I 7; I 20-I 26.

11) Apart from Rose's fundamental study, see, e.g., Nils Arne Pedersen, 'Early Manichaean Christology, primarily in Western Sources,' in: Peter Bryder (ed.), Manichaean Studies, (Lund I988), I 57-I90 for the Western sources in general; Iain Gardner, 'A Manichaean Liturgical Codex Found at Kellis,' Orientalia 62 (I 993) 30-59 for the new finds of Manichaean texts at the site of ancient Kellis in Egypt; and the classic work of Ernst Waldschmidt o. Wolfgang Lentz, Die Stellung Jesu im Manichäismus (Abhandlungen der Preussischen Akademie der Wissenschaften 4), (Berlin 1926) for the texts from Central Asia discovered along the Silk Road in Turfan and Tun-huang at the beginning of the twentieth century. Cf., e.g., Werner Sundermann, 'Christ in Manichaeism,' Encyclopaedia Iranica 5 (I992) 535-539 and, as regards Manichaean art, Zsuzsanna Gulácsi, 'A Manichaean "Portrait of the Buddha Jesus" (Yishu Fo Zheng),' Artibus Asiae 69 (2009) 9I-I 45. 
such as the Coptic Kephalaia, ${ }^{12}$ the Psalm-Book, ${ }^{13}$ the Homilies ${ }^{14}$ and, not least, the Cologne Mani Codex. ${ }^{15}$

A careful reading of the continuation of Augustine's account in conf. 3,6, Io further demonstrates his accuracy. He appears to make use of expressions and technical terms typical to the Manichaeans. ${ }^{16}$ His (often very subtle) references and allusions indicate that at the time Augustine wrote his conf. he knew their writings very well. ${ }^{17}$ In conf. 3,6, Io Augustine relates that the Manichaeans

12) Cf. Hans Jakob Polotsky \& Alexander Böhlig (ed., tr.), Kephalaia, Band I, I, (Stuttgart I940), e.g., I0 I, 24-25 (Mani who proclaimed the Truth everywhere); I 5 I, 20-22 (God the Father of Truth); I86,22-23 (Mani's religion as the Truth); I 88,23-24 (the M. have found the Truth more than all people in the world).

13) Psalm-Book (see above, n. 7), e.g., 3, I2 ("Glory and victory to the Spirit of Truth, our God, our Lord Mani"); 6,23 ("the knowledge of the Truth"); 9, 4-5 ("Let us bless our Lord Jesus who has sent to us the Spirit of Truth"); 9,8-9 ("When the Holy Spirit came he revealed to us the way of Truth"); I I,29-30 ("Glory and victory to our Lord Mani, the Spirit of Truth, that cometh from the Father").

14) Hans Jakob Polotsky (ed., tr.), Manichäische Homilien, (Stuttgart I 934), e.g., 5, 5 (Mani's Truth); 29,7 (Mani's judgement seat of Truth); 48, I-2 (Mani wishes to proclaim the Truth before King Shapur); 75,2 I (praise to Mani's Truth). Cf. the new edition by Nils Arne Pedersen, Manichaean Homilies (CFM, Series Coptica II), (Turnhout 2006), same pages and lines. 15) In the $C M C$ the Greek word alètheia occurs no less than 22 times, most characteristically in $C M C$ 64,8 (the beginning of a quotation from Mani's letter to Edessa; cf. the passage from this same letter in $C M C$ 65,6) and in $C M C$ 66,6, a quote from the prologue of Mani's Gospel: "I, Mani, Apostle of Jesus Christ through the will of God, the Father of Truth." The notion of alètheia is also conspicious in the newly discovered "Prayer of the Emanations," a Greek text from Kellis. Best edition (with commentary): Iain Gardner, Kellis Literary Texts, Volume 2, (Oxford 2007), I I I-I 28; latest commentary: Iain Gardner, 'Manichaean Ritual Practice at Ancient Kellis: A New Understanding of the Meaning and Function of the socalled Prayer of the Emanations,' in: Jacob Albert van den Berg, Annemaré Kotzé, Tobias Nicklas \& Madeleine Scopello (eds.), 'In Search of Truth': Augustine, Manichaeism, and Other Gnosticism. Studies for Johannes van Oort at Sixty (NHMS 74), (Leiden-Boston 20 I I), 245262.

16) Cf. Johannes van Oort, 'Manichaeism and Anti-Manichaeism in Augustine's Confessiones,' in Luigi Cirillo \& Aloïs Van Tongerloo (eds.), Atti del Terzo Congresso Internazionale di Studi 'Manicheismo e Oriente Cristiano Antico', (Turnhout-Leuven I 997), 235-248.

17) Cf. Johannes van Oort, 'Young Augustine's Knowledge of Manichaeism. An Analysis of the Confessiones and Some Other Relevant Texts,' Vigiliae Christianae 62 (2008) 44I-466, partly in opposition to J.K. Coyle, 'What Did Augustine Know about Manichaeism When He Wrote His Two Treatises “De moribus”?, in: Johannes van Oort, Otto Wermelinger \& Gregor Wurst (eds.), Augustine and Manichaeism in the Latin West (NHMS 49), (LeidenBoston-Köln 200I), 43-56 and idem, 'Saint Augustine's Manichaean Legacy,' Augustinian Studies 34 (2003) I-22 (both studies reprinted in Coyle, Manichaeism and Its Legacy (NHMS 69), (Leiden-Boston 2009), 25 I-263; 307-328). 
spoke to him about God "frequently and in various ways with mere voice and with the support of many huge tomes." 18 The impressive books were used as the dishes (fercula) in which they, instead of the true God, "served up the sun and the moon." ${ }^{19}$ Augustine explicitly adds that the Manichaeans placed these "dishes" before him and that they contained "splendid hallucinations." ${ }^{20}$ It appears that also in fourth-century Roman Africa, apart from the oral message of the Manichaeans by means of discourses, books were employed to disclose their doctrine. Augustine's account of his making acquaintance with the Manichaeans even seems to provide a unique piece of information, namely that even among the African Manichaeans Mani's so-called "Image" (Greek: Eikôn; Persian/Parthian: Ärdahang), the painted picture book illustrating the most essential aspects of his doctrine, was in use. ${ }^{21}$ In the account of his initial acquaintance with the Manichaeans, Augustine hints at their presentation of (pictorial) books. ${ }^{22}$

In the suqsequent narrative of his life story in the Confessions Augustine also tells that he actually read Manichaean books. His account of Monnica's meet-

18) Conf. 3,6, I0: "cum te illi sonarent mihi frequenter et multipliciter, voce sola, et libris multis et ingentibus!"

19) Ibidem: "et illa erant fercula, in quibus mihi esurienti te inferebatur pro te sol et luna."

20) Ibid.: "et apponebantur adhuc mihi in illis ferculis phantasmata splendida."

21) This book probably was an appendix to, but different from Mani's most important canonical writing, i.e. the Living Gospel. Perhaps Mani's Epistula Fundamenti might be identified as the written commentary added to this Picture Book or Drawing. Another possiblity is that the Icon was designed to illustrate the contents of Mani's Pragmateia (or Treatise, Essay). Perhaps it was this canonical writing of Mani's (and not his Living Gospel) that was also well known among the Western Manichaeans and, after the Epistula Fundamenti as the first and the Thesaurus as the second canonical text, belonged to the quinque auctores which, as "scripturae Manichaei," were present during the second day of A.'s disputation with Felix (cf. c. Fel. I, I 4). See further below.

22) This might be corroborated by his use of the verb imaginari a few lines further on in conf. 3,6, I0: "At illa [sc. phantasmata quae apponebantur mihi in illis ferculis] nec similia erant ullo modo tibi, sicut nunc mihi locuta es, quia illa erant corporalia phantasmata, falsa corpora, quibus certiora sunt uera corpora ista, quae uidemus uisu carneo, siue caelestia siue terrestria: cum pecudibus et uolatilibus uidemus haec, et certiora sunt, quam cum imaginamur ea. Et rursus certius imaginamur ea quam ex eis suspicamur alia grandiora et infinita, quae omnino nulla sunt." Besides, there might be a subtle reference to such a picture book in A.'s statement when speaking of the doctrine of the M. in conf. 5, 10,20: "quam malignam mentem per illam terram repentem imaginantur." One may also compare A.'s reference to the M. in conf. 9,4, I0: "Volentes enim gaudere forinsecus facile uanescunt, et effunduntur in ea, quae uidentur et temporalia sunt, et imagines eorum famelica cogitatione lambiunt." 
ing with an African bishop is already relevant in this context (conf. 3, I 2,2 I). This Catholic bishop (in popular tales and sentiment he is often supposed to be Ambrose, which is completely incorrect) is reported to have said that Augustine "by his reading (legendo) will discover what that error (sc. the Manichaean haeresis) is and how vast an impiety." 23 "Legendo" almost certainly refers to the Manichaean books - and not, as is often supposed, to the biblical Scriptures: Augustine continues by telling of the bishop's own experience as a former Manichaean who "without argument or proof from anyone" (nullo contra disputante et conuincente) discovered from their books that the Manichaeans should be shunned, and therefore the bishop's answer to Monnica was: "leave him there" (sine illum ibi), namely in that heresy, sothat he will have the same experience.

But another indication seems to be even more important in this context. In regard to the African Catholic bishop, Augustine provides some important details: as a young boy (paruulus) he was consigned by his mother to the Manichaeans and, in those years, as an Auditor, "he had not only read nearly all their books, but had even copied them." ${ }^{24}$ From the recent discoveries of Manichaean texts in the Dachleh Oasis in Egypt, at the site of ancient Kellis some $900 \mathrm{~km} \mathrm{SSW}$ of Cairo, we got perfect illustration to this highly interesting piece of information. A number of manuscripts have been unearthed in Kellis which strongly indicate that Manichaean Hearers (as well as Elect) were involved in the reading and even copying of texts. Young Hearers' involvement may be inferred from the wide range of Manichaean psalms often written in unpracticed handwritings, ${ }^{25}$ and in particular from one of the personal letters sent by a certain father Makarios to his son Matheos. This Matheos, obviously a young Hearer, is not only encouraged to copy Manichaean books (apparently including books of Mani himself), but also to study them (P. Kell. Copt. I9). ${ }^{26}$

Following the order of the Confessions, it is in book 5,3,6 that we find Augustine unequivocally indicating his personal reading of Mani's own writings: he compared philosophers' statements based on calculations, the order of seasons, and the visible manifestations of the stars "with the sayings of Mani (dicta

\footnotetext{
23) Conf. 3, I 2,2 I: "ipse legendo reperiet, quis ille sit error et quanta impietas."

24) Conf. 3, I 2,2 I: "Simul etiam narrauit, se quoque paruulum a seducta matre sua datum fuisse Manichaeis, et omnes paene non legisse tantum uerum etiam scriptitasse libros eorum."

25) Iain Gardner, Anthony Alcock \& Wolf-Peter Funk, Coptic Documentary Texts from Kellis, Volume I, (Oxford I999), 77.

26) Gardner, Alcock \& Funk, Coptic Documentary Texts from Kellis, I 56-I65, esp. I60.
} 
Manichaei), which ${ }^{27}$ he has written on these subjects very copiously and foolishly." 28

Other passages indicating Augustine's actual reading are in conf. 5,7, I 2-I 3 where he relates his initial estrangement from the Manichaeans after he had met their bishop Faustus. ${ }^{29}$ The story of the meeting with Faustus is concluded with the explicit remark: "My study of the writings of Mani was thus checked."30 In his work Against Mani's Fundamental Letter Augustine expresses similar things regarding the period of his study of Manichaean doctrine, ${ }^{31}$ and he also speaks of the writings of the Manichaeans as their "litterae." 32 Both sources seem to provide a solution to the often observed "inconsistency" in Augustine's accounts of the duration of his Manichaean years. ${ }^{33} \mathrm{He}$ was a Hearer who ardently studied the Manichaean writings for (at least) nine years, namely until his meeting with Faustus at the end of 382 (or the beginning of 383 ). After that long period he still remained a Manichaean, certainly during his first Roman sojourn, ${ }^{34}$ although by then he was no longer that ardent Hearer who enthusiastically studied Manichaean documents and passionately tried to convince others. ${ }^{35}$ In $382 / 3$ his enthousiasm for this "gnostic" 36 variety of

27) The well-known and perhaps best ancient mss. read "quae," not "qui." Cf. van Oort, 'Young Augustine's Knowledge' (see above, n. I7) 452-453 n. 4I.

28) Conf. 5,3,6: "Multa tamen ab eis ex ipsa creatura uera dicta retinebam, et occurrebat mihi ratio per numeros et ordinem temporum et uisibiles attestationes siderum et conferebam cum dictis Manichaei, quae de his rebus multa scripsit copiosissime delirans."

29) E.g., conf. 5,7, I 2: "Libri quippe eorum pleni sunt longissimis fabulis de caelo et sideribus et sole et luna: quae mihi eum [sc. Faustum], quod utique cupiebam, conlatis numerorum rationibus, quas alibi ego legeram, utrum potius ita essent, ut Manichaei libris continebantur, an certe uel par etiam inde ratio redderetur, subtiliter explicare posse iam non arbitrabar."

30) Conf. 5,7,1 13 : "Refracto itaque studio, quod intenderam in Manichaei litteras."

31) C. ep. Man. Io, I I: "sed tamquam ipse a uobis [sc. M.] discere studeam, quod nouem annis non potui."

32) Ibid.: "multo minus uestris litteris credam."

33) E.g., Pierre Courcelle, Recherches sur les Confessions de saint Augustin, (Paris 1950) (19682), 78; L.C. Ferrari, 'Augustine's “Nine Years” as a Manichee,' Augustiniana 25 (1975) 210-2 I6.

34) E.g., conf. 5, I0, $18 \mathrm{ff}$.

35) E.g., conf. 4, I, I: "Per idem tempus annorum nouem, ab undeuicensimo anno aetatis meae usque ad duodetricensimum, seducebamur et seducebamus." Cf., e.g., duab. an. 9, I I. 36) As is well known, the term "gnostic" is a very disputed one in modern research. The so-called "Gnostics" nearly never called themselves this way, but most often considered themselves to be (some sort of) Christians. Many scholars strongly argue against using the term, but to speak of "alternative" Christians or non-mainstream Christians and the like. 
Christianity was checked, and his study of the writings of the Manichaeans only resumed in later years, when he had become a Catholic presbyter and bishop. ${ }^{37}$

The early study of the Manichaean litterae may explain Augustine's detailed knowledge of the Manichaean doctrines already discernable in his early writings. In the twin treatises The Morals of the Catholic Church and the Morals of the Manichaeans (c. 388) it is in particular the second book that testifies to an amazing insider's knowledge. Augustine never indicates that he first sat down to study texts of the Manichaeans in order to refute them. But his discussion of the Manichaean concept of the kingdom of darkness and its qualities (mor. 2, I 4 ff.), for instance, is that of a true expert. He states that the congruentia of the kingdom of darkness deceived "your author" [i.e., Mani] and led him to compose lies (mor. 2,17). And he even remarks: "This is not what we find in the books of Mani: there it is very often (saepissime) indicated and very often (saepissime) stated that God took care that he would not be invaded."38 Augustine also speaks of "what Mani wrote" 39 and "what even that founder of your sect was never forced to say." ${ }^{40}$

In his dispute with the Manichaean presbyter Fortunatus in 392, Augustine testifies to a thorough knowledge of (at least) Mani's Epistula Fundamenti and Thesaurus. ${ }^{41}$ Further, in his Against Mani's Fundamental Letter (c. ep. Man., 396/7), he imparts that an (annotated) copy of Mani's Epistula fundamenti was at his disposal. ${ }^{42}$ Nowhere in this refutation does he say that he had acquired

37) As is indicated in regard to Adimantus's Disputationes in retr. I, 22, I and in case of Faustus's Capitula in c. Faust. I, I. Concerning all of Adimantus's Disp. known to us, however, one may have some doubts, because in Gn. adu. Man. (usually dated 388-389/390, i.e. at least some years before $c$. Adim.), A. clearly indicates that he was well acquainted with part of these Disp. Cf. J.A. van den Berg, Biblical Argument in Manichaean Missionary Practice: The Case of Adimantus and Augustine, (Leiden-Boston 2010), 103. Moreover, the account of his first meeting with the M. in conf. 3,7, I2-I 3 seems to reveal the same: cf. J. van Oort, Jerusalem and Babylon. A Study into Augustine's City of God and the Sources of His Doctrine of the Two Cities, (Leiden etc. I991), 37-39.

38) Mor. 2,25: "Non hoc sonant libri Manichaei; cauisse Deum ne inuaderetur ab hostibus, saepissime ibi significatur, saepissime dicitur."

39) Mor. 2,23: "Immo sectam illam deserite, nam si hoc quod ille [sc. Mani] scripsit destiteritis credere ac dicere, Manichaei utique non eritis."

40) Mor. 2,26: "quod neque auctor ille uester ullo modo dicere cogeretur."

41) Johannes van Oort, 'Heeding and Hiding their particular Knowledge? An Analysis of Augustine's Dispute with Fortunatus,' in: T. Fuhrer (ed.), Die christlich-philosophischen Diskurse der Spätantike, (Stuttgart 2008), I I 3-I 2 I.

42) Cf. retr. 2,2, I: "Liber contra epistulam Manichaei quam uocant fundamenti prin- 
this Letter recently, ${ }^{43}$ or does he give the impression that its subject matter was new to him. Rather, Augustine criticizes a text he is thoroughly familiar with and, moreover, he feels himself qualified to speak about the precise contents of other writings of Mani. ${ }^{44}$

From the disputation with the Manichaean doctor Felix (404) one gets the very same impression. In this instance the discussion is about the (confiscated) works of Mani, a codex containing the "quinque auctores" to which, in any case, Mani's Epistula Fundamenti and Thesaurus turn out to belong. ${ }^{45}$ Nowhere it is indicated that Augustine, in order to prepare properly for the dispute, first studied this codex. In a striking way, however, and evidently from memory, he quotes Mani's Thesaurus in order to prove that Mani has a doctrine of free will. ${ }^{46}$

The same expertise resounds throughout the extensive Against Faustus written some years earlier: although bishop Faustus's so-called Capitula turn out to be new (while newly written) to Augustine, he displays a remarkable erudition in a wide range of typical Manichaean themes and doctrines. ${ }^{47}$ His statement that "all of Mani's letters begin in this fashion: 'Mani, apostle of Jesus Christ" "48 is very characteristic, and unique is his remark on a certain Amatorium canticum in use among the Manichaeans: "Do you recall your Song of the Lovers in which you describe the supreme reigning monarch, forever sceptrebearing, crowned with flowers and of fiery countenance?" ${ }^{99}$ In answer to this question Augustine displays his intimate knowledge of the Manichaean "theology" by describing from this source both the supreme God and his kingdom of worshipping deities. ${ }^{50}$

cipia eius sola redarguit; sed in ceteris illius partibus adnotationes ubi uidebatur adfixae sunt, quibus tota subuertitur et quibus commonerer, si quando contra totam scribere vacuisset."

43) Pace the suggestion of Coyle, "Epistulam Manichaei quam vocant fundamenti, Contra," Augustine through the Ages, 3 I I.

44) See n. I 29 below.

45) C. Fel. I, I 4 .

46) C. Fel. 2,5.

47) Further on $c$. Faust. below.

48) C. Faust. I 3,4: "omnes tamen eius epistulae ita exordiuntur: Manichaeus apostolus Iesu Christi."

49) C. Faust. I 5,5: "annon recordaris amatorium canticum tuum, ubi describis maximum regnantem regem, sceptrigerum perennem, floreis coronis cinctum et facie rutilantem?."

50) C. Faust. I 5, 5-6. 
In several of his other writings Augustine also reveals a distinctive expertise, which is evidently based on firsthand knowledge. ${ }^{51}$ Moreover, the succinct survey of the Manichaeans, their doctrines, Church organization, and ethics in less than I660 words in haer. $46(428-430)$ is not only highly to the point but, in several respects, also unique. ${ }^{52}$ Near the end of his life Augustine gives another proof of his expertise based on his intimate acquaintance with the Manichaean writings. After Julian has brought to his knowledge a letter of Mani to a certain Menoch, Augustine is able to express genuine surprise: he had never been aware of the existence of this letter. ${ }^{53}$

\section{Analysis of Individual Writings}

Starting from the above observations, the place of the Manichaean Christians in a number of Augustine's writings will be outlined, while at the same time the many specific traits and peculiarities will be highlighted in order to provide an overview that is as complete as possible. Already the Indiculum attributed to Augustine's disciple Possidius — a writing in all probability based upon a catalogue of his works drawn up by Augustine himself ${ }^{54}$ _ gives the impression of a whole corpus of anti-Manichaean writings, ${ }^{55}$ a collection which in many

51) Cf., e.g., on ciu.: J. van Oort, 'Manichaeism in Augustine's De ciuitate Dei,' in: E. Cavalcanti (ed.), Il 'De ciuitate Dei': L'opera, le interpretazioni, l'influsso, (Roma I996), I93-2 I 4. 52) Further on haer. below.

53) C. Iul. imp. 3, I72: "Si dicam tibi istam Manichaei epistulam me omnino nescire" etc. In former research, the so-called Epistula ad Menoch, forwarded to Julian of Eclanum by his friend Florus from Constantinople, was considered to be a falsification (though testifying to an intimate knowledge of Manichaean tenets). See, e.g., G.J.D. Aalders, 'L'Épître à Menoch, attribuée à Mani,' Vigiliae Christianae I 4 (I960) 245-249. As regards its genuineness, M. Stein, Manichaica Latina. Band I: Epistula ad Menoch (Papyrologica Coloniensia, 27, I), (Opladen I 998), remained in dubio. Geoffrey Harrison \& Jason David BeDuhn, 'The Authenticity and Doctrine of (ps.) Mani's Letter to Menoch' in: Paul Mirecki \& Jason D. BeDuhn (eds.) The Light and the Darkness. Studies in Manichaeism and Its World (NHMS 50), (Leiden-Boston-Köln 200I), I28-I72, offer conclusive arguments for its authenticity.

54) It is, therefore, best indicated as being the (in fact: anonymous) Indiculum of Hippo. Cf. F. Dolbeau, 'La survie des œuvres d'Augustin. Remarques sur l' Indiculum attribué à Possidius et sur la bibliothèque d'Anségise,' in: Donatella Nebbiai-Dalla Guarda \& Jean-François Genest (eds.), Du copiste au collectioneur. Mélanges d'histoire des textes et des bibliothèques en l'honneur d'André Vernet, (Turnhout I999), I 2-13.

55) Cf. André Wilmart, 'Operum S. Augustini Elenchus a Possidio eiusdem discipulo Calamensi episcopo digestus,' Miscellanea Agostiniana 2, (Roma I93 I), I 49-233. 
respects is comparable to his corpus of, for instance, the anti-Donatist and the anti-Pelagian writings. ${ }^{56}$ Without pretending to be exhaustive, the following overview - its order in accordance with the arrangement of Augustine's writings in the Retractationes - is intended to provide an introductory but at the same time comprehensive overview.

The Morals of the Catholic Church and the Morals of the ManichaeansThough in earlier books Augustine touches upon Manichaean themes, ${ }^{57}$ the twin treatises mor. (Rome 387/8 - Thagaste 388/9) are his first writings fully directed against the Manichaeans. Throughout the two books they are directly addressed as "you" and "you Manichaeans." 58 According to its title Book I is "on the morals of the Catholic Church," but its main theme may be specified as a confrontation of two ways of Christian life practiced in two kinds of Christian churches.

Already from the first book a number of characteristics of the Manichaeans come to the fore: they claim that the citations from the Old Testament found in the New Testament are interpolations ( I4); they reject the God of the Old Testament (I6) and warn not to think of God as having a human form (I7); they hold that the soul is part of God (20); they claim certain passages of the New Testament, for instance in Paul's Letter to the Romans, to be corrupt (6I); they habitually speak ill of the Catholic Church (76-77) and on that account recruit ignorant Catholics into their sect $(80)$; they state that true believers, "because they are renewed by baptism," should not procreate children nor own fields, homes, or any money (78). ${ }^{59}$ For all these and similar reasons (e.g., because they worship sun and moon, 37), the Manichaeans are not (true) Christians. ${ }^{60}$ Therefore, they should "listen to the singular way of life and

56) Cf. the sections "Adversvs Donatistas" and "Contra Pelagianistas" in the Indiculum (or Elenchus) in Wilmart's edition, I68-I7I, I7I-I73, the many similarities as regards their wording, the (initial) division of the contra- or adversvs-writings in regular writings (libri etc.), epistulae, and tractatus, etc.

57) E.g., Acad. I,3; 2,8; ord. 2, I7,46.

58) The last mentioned address ("M.") in I,59.65.68.74 as well as in 2,2 (cf., e.g., 2,23: "Manichaei utique non eritis").

59) Mor. I,78: "Quid calumniamini, quod fideles iam baptismate renouati procreare filios et agros ac domos pecuniamque ullam possidere non debeant?”

60) Mor. I,37 ("christiani non sint qui solem et lunam non modo diligendos sed etiam colendos putant") and I,62 ("Quis enim non uideat eos qui contra Scripturas christianas haec audent dicere, ut illud non sint quod homines suspicantur, certe tamen non esse christianos?"). Cf. retr. I,6 (7), I: "Iam baptizatus autem cum Romae essem, nec ferre tacitus possem Manichaeorum iactantiam de falsa et fallaci continentia uel abstinentia, qua se ad imperitos decipiendos, ueris Christianis, quibus comparandi non sunt, insuper praeferunt 
continence of the perfect Christians" (65), i.e. "the most holy Christians of the Catholic faith" (66).

The second book, explicitly "on the morals of the Manichaeans," discloses a great many of their teachings, in particular their moral precepts. Its first part ( $\mathrm{I}-\mathrm{IO}$ ) focuses on theoretical issues like God as the uncreated substance and highest good, who is immutable, incorruptible, and inviolable, and whose opposite is utter nothingness; and in particular on the question of the origin of evil. The issues discussed and the answers given in this section evidently parallel those in The Free Choice of the Will (and will be repeated by Augustine in all his subsequent anti-Manichaean writings). Thus, in the Chapters I-IO, Augustine states that evil is simply a falling away from being; that God cannot be the author of evil or of the falling away from being; that evil is not an essence or substance, ${ }^{61}$ but a privation of good; that rational souls fall away from God by their own free choice; and that whatever is, insofar as it is, comes from God, but, insofar as it falls away from being, it does not come from God. In the following Chapters (I I-I 2) it is stated that, if any substance (such as fire or poison) is evil because it does harm, then the very light the Manichaeans worship cannot be defended from this charge since its rays cause blindness. In all these cases, however, we should not speak of evil but of unsuitability (inconuenientia), and unsuitability is not a substance. Augustine continues by declaring that the Manichaeans should stop saying "that evil is a region immensely broad and long; that evil is a mind wandering through that region; that evil is the five caves of the elements, one full of darkness, another full of waters, another full of winds, another full of fire, and another full of smoke; that evil is the animals born in each of those elements, crawling ones in the darkness, swimming ones in the waters, flying ones in the winds, four-legged ones in the fire, two-legged ones in the smoke." ${ }^{2}$ These and other parts of their myth (such as the story that the aborted fetuses, which fell from heaven to earth and were still living, reproduced offspring and again formed a conspiracy) could by no means occur as the Manichaeans relate (I 4). Moreover, there

...," and for their claim to be the true Christians, e.g., Faustus in c. Faust. I, 2.

61) Or "nature." Note A.'s interesting remark on terminology in mor. 2, 2: "essence" (derived from esse) is a new term for "substance"; the ancients did not have these terms but used "nature" instead of "essence" and "substance."

62) Mor. 2, I4: "malum esse terram per immensum profundam et longam, malum esse mentem per terram uagantem, malum esse quinque antra elementorum, aliud tenebris, aliud aquis, aliud uentis, aliud igni, aliud fumo plenum, malum esse animalia in illis singulis nata elementis, serpentia in tenebris, natantia in aquis, uolatilia in uentis, quadrupedia in igne, bipedia in fumo." 
are many other inconsistencies in their representation of the kingdom of evil ( I 5-I 8).

Next, Augustine provides a comprehensive description of the Manichaean ethical teaching of the three seals (the seal of the mouth; the seal of the hands; the seal of the breast: signaculum oris; signaculum manuum; signaculum sinus). First he gives a summary that seems to show significant similarities with original Manichaean Kephalaia literature: "He (i.e., Mani?) says, when I mention the mouth, I want you to understand all the senses that are found in the head. When I mention the hand, I want you to understand every action. When I mention the breast, I want you to understand all sexual lust" (I9). ${ }^{63}$ The Chapters 20-53 mainly deal with the signaculum oris, the Chapters 54-64 with their signaculum manuum, and the following chapters with the signaculum sinus. On the one hand Augustine tries to indicate the inconsistencies and even absurdities of the ethical teachings of the Manichaeans, on the other hand he focuses on the many transgressions of their own precepts. Augustine's repeated "inquit," "ait," "dicit" etc., when relating the teachings of the Manichaeans, strongly gives the impression that he is quoting from Manichaean writings. ${ }^{64}$ They are also hinted at in phrases such as "what Mani wrote,"65 "the books of Mani," 66 "that author of yours," 67 or "the opinion of your founder." ${ }^{68}$ Near the end of the work Augustine tells the interesting story of the (unsuccessful) effort of a Hearer ${ }^{69}$ to establish some sort of monastery in his house in Rome, an endeavour based "on the rule of life from the letter of Mani." ${ }^{70}$ Both from this story ${ }^{71}$ and from the context of a reference to what he "recently heard in

63) Mor. 2, I9: "Sed cum os, inquit, nomino, omnes sensus qui sunt in capite intelligi uolo, cum autem manum, omnem operationem, cum sinum, omnem libidinem seminalem."

64) Cf. his references to biblical writings being also introduced throughout mor. (and elsewhere) by "inquit," "ait," "dicit," "dicatur est," "cum dicitur" and the like.

65) Mor. 2,23: "quod ille scripsit."

66) Mor. 2,25: "libri Manichaei."

67) Mor. 2,26: "auctor ille uester."

68) Mor. 2,30: "uestri auctoris sententia."

69) He seems to be the same person as the Constantius mentioned in c. Faust. 5,5, and there described as being "now our brother as a Catholic Christian" (modo iam frater noster catholicus christianus).

70) Mor. 2,74: "Proposita est uiuendi regula de Manichaei epistola." One may argue from this fact that A. learnt of some sort of monastic life according to a rule first among the M.!

71) Cf. mor. 2,74: "Romae autem me absente quid gestum sit"; "et ego quidem postea Romae cum essem, omnia uera me audisse firmaui; quamuis tam familiaris et mihi probatus, qui praesens erat, ad me rem pertulerat, ut omnino dubitare non possem.” 
Carthage," 72 it may be deduced that, even after his conversion to the Catholic Church, Augustine was in close contact with Manichaeans.

The Free Choice of the Will-The three books in dialogue form, begun in Rome 387-388 and finished in Hippo 395, discuss the problem of evil. The question "unde malum: whence is evil?" was—so Augustine tells his dialogue partner Evodius - the issue disturbing him intensely when he was an adolescent and drove him to the heretical Manichaeans. ${ }^{73}$ Throughout the work the Manichaean problem is in the background, but in particular in 2,54, ${ }^{74} 3,166^{75}$ and $3,36^{76}$ Augustine directs himself against the opinions of the Manichaeans. It is, in essence, their doctrine of a natura mala that is attacked and rejected mainly in the light of Plotinian doctrines.

On Genesis against the Manichaeans-The work in two books, probably written 388-390, is Augustine's first endeavour to explain (the first parts of) Genesis, in particular the Creation account. In mor. I, I Augustine already seems to refer to it when he speaks of books in which he has answered the attacks of the Manichaeans on the Law that is called the Old Testament. ${ }^{77}$ In Book I Augustine attempts an explanation of Gen. I, I-2,4a; in Book 2 an explanation of Gen. 2,4b-3,24. As a rule the commentary in Book I is presented in the following order: the biblical verses are quoted; then the opinions of the Manichaeans are mentioned and rejected; after that the "true meaning" of the texts is presented according to a literal interpretation. In Book 2 Augustine decides on a figurative interpretation, ${ }^{78}$ which comprises allegorical, prophetic, and spiritual explanation. Here the Manichaeans, though always in

72) Mor. 2,26.

73) Lib. arb. I,2,4: "Eam quaestionem moues, quae me admodum adolescentem uehementer exercuit, et fatigatum in haereticos impulit atque deiecit." Cf., e.g., conf. 3,7, 2.

74) Lib. arb. 2,54: "nulla natura occurrit quae non sit ex Deo."

75) Lib. arb. 3, 16: “... corporum quorumlibet quamlibet splendissimum fulgor, quem pro ipsius summi Dei substantia quidem [sc. the M.], quamuis cum magno errore, uenerantur."

76) Lib. arb. 3,36: “... propter loquaces ... aut insidiosos homines [sc. the M.] tantam quaestionem breuissima complexione peragamus. Omnis natura quae minus bona fieri potest, bona est. (...) ... omnis natura in quantum natura est, bona est. (...) Omnis igitur substantia aut Deus, aut ex Deo; quia omne bonum aut Deus, aut ex Deo.”

77) Mor. I. I: "In aliis libris satis opinor egisse nos, quemadmodum Manichaeorum inuectionibus, quibus in legem quod uetus testamentum uocatur ... feruntur ... possimus occurrere." In all probability, the Preface to mor. is written after the work was completed and perhaps even after the completion of $G n$. adu. Man.

78) Gn. adu. Man. 2, I: "quae omnis narratio non aperte sed figurate explicatur." 
the background, are less frequently addressed..$^{79}$ Their objections appear to stem from oral disputations in which Augustine once took an active part and the focus of which was the first chapters of Gen.

From Book I in particular a long list of questions can be deduced: In what principium did God create? If God created heaven and earth in the beginning of time, what did He do before he created heaven and earth? What motivated Him to (suddenly) create heaven and earth? How did God create heaven and earth in the beginning, if there was already an invisible and incomposed earth? Was God in the darkness before He created the light? Etc. ${ }^{80}$ The objections of the Manichaeans are easily recognizable in that they are introduced by expressions such as "quaerunt," "dicunt," "reprehendunt," "solent dicere," "interrogant," "calumniantur," "aiunt," "solent reprehendere.” Once Augustine, after quoting Gen. I, 6-8, remarks that he does not remember that the Manichaeans criticized these words ${ }^{81}$ this remark is quite understandable, because their myth spoke of the making of the firmament positively. At another place Augustine compares the Manichaeans to the Jews: neither of them understands the sacramentum of the sabbath. ${ }^{82}$

In Book 2 Augustine once addresses the Manichaeans directly. ${ }^{83} \mathrm{He}$ concludes the work, after having recapitulated some of the Manichaeans' main

79) Most conspiciously in Gn. adu. Man. 2,8. I I. I9.38.40.4I.42-43.

80) Gn. adu. Man. I, 3: "Quod scriptum est: In principio fecit Deus coelum et terram, quaerunt, in quo principio; et dicunt: $\mathrm{Si}$ in principio aliquo temporis fecit Deus coelum et terram, quid agebat antequam faceret coelum et terram? et quid ei subito placuit facere, quod nunquam antea fecerat per tempora aeterna?"; 4: "Si autem non dicunt: Quid placuit Deo subito facere coelum et terram, sed tollunt inde, subito; et hoc tantum dicunt: Quid placuit Deo facere coelum et terram?"; 5: "Quomodo fecit Deus in principio coelum et terram, si iam et terra erat invisibilis et incomposita?"; 6: "In tenebris ergo erat Deus, antequam faceret lucem?"; 7: "Unde erant ipsae tenebrae super abyssum, antequam faceret Deus lucem? quis illas fecerat vel genuerat?"; 8: "Aqua ergo erat habitaculum Spiritus Dei, et ipsa continebat Spiritum Dei?"; 9: "Unde erat ipsa aqua super quam ferebatur Spiritus Dei? numquid enim superius scriptum est quod Deus aquam fecerit?" Etc.

81) Gn. adu. Man. I, I7: "Haec non memini Manichaeos reprehendere solere."

82) Gn. adu. Man. I,33: "et illi carnaliter obseruando, et isti carnaliter exsecrando."

83) Gn. adu. Man. 2, I I: "aut etiam, ut uos dicitis, naturae contrariae sordibus inquinatur." A certain benevolent-protreptic character of $G n$. adu. Man., which may underscore the likely presence of aduersus (and not: contra) in its title, seems to come to the fore in, e.g., I,32 and 2,I9. Near the very end of the work $(2,43)$ the reader is invited to make up his mind: "cum ergo illa illi [sc. the M.], et nos ista dicimus, unusquisque eligat quid sequatur." 
objections, ${ }^{84}$ with some sort of synoptical comparison of the Manichaeans' error and the Catholic truth. ${ }^{85}$

Though The Literal Interpretation of Genesis. An Unfinished Book (c. 393/4) and The Literal Interpretation of Genesis (c. 40 I/2-c. 4I 5/6) are prompted by the Manichaeans' critique as well, Mani's followers are not openly addressed in the first work, ${ }^{86}$ and in the second writing of no less than twelve books they are mentioned rather infrequently. The most important passages are $G n$. litt. 7, I I, I7 (the Manichaeans, "who consider themselves to be Christians," have a completely wrong opinion on the soul, an opinion which is even worse than that of the pagans); 8,2,5 (Augustine's former reasons to give an allegorical explanation of Gen., namely to counter the Manichaeans); and a critical remark on the Manichaean two souls theory in I0, I3,22.

The True Religion - The final of Augustine's writings prior to his ordination (uer. rel. is usually dated to the end of 390) addresses his former benefactor Romanianus, who was once converted to the Manichaeans by Augustine, and by then was still adhering to them. Among Augustine's anti-Manichaean works uer. rel. stands out for its diction, composition, and cogent argument. Its main theme is to prove that the One God (unus deus) is the origin and first principium of all naturae. ${ }^{87}$

In the prologue $(\mathrm{I}-2 \mathrm{O})$ the Manichaeans and their doctrines are mentioned or alluded to several times. ${ }^{88}$ Augustine explicitly states that his writing is particularly directed "against those who opine that there are two natures or

84) Gn. adu. Man. 2,42: "Quare fecit Deus hominem, inquiunt, quem peccaturum sciebat?"; "Sic eum faceret, inquiunt, ut non peccaret"; "Non admitteretur, inquiunt, diabolus ad eius mulierem"; "Non fieret, inquiunt, mulier"; "Iterum dicunt: Quis fecit diabolum?”; "Vel ipsum, aiunt, non faceret Deus, si eum peccaturum esse sciebat"; "Ergo, inquiunt, bonus est diabolus, quia utilis est?"

85) Cf. retr. I,IO, I: "Deinde in fine libri errori Manichaeorum fidem catholicae ueritatis opposui, quid illi dicant et nos quid dicamus breuiter aperteque complectens." In regard to the M. it is claimed in Gn. adu. Man. 2,43 that "illi dicunt naturam Dei esse in miseria"; "illi dicunt naturam Dei cogi ab ipso Deo ad poenitentiam peccatorum"; "illi dicunt naturam Dei ab ipso Deo accipere veniam"; "illi dicunt naturam Dei necessitate esse mutabilem"; "illi dicunt naturae Dei nocere aliena peccata"; "illi dicunt esse naturam mali cui Deus coactus est naturae suae partem dare cruciandam.” Quite the same points return, for instance, in the dispute with Fortunatus.

86) References may be found in Gn. litt. imp. 4, I I ("haereticis, qui ueteri testamento aduersantur") and 5,24 ("nonnulli nimis errantes haeretici").

87) Cf. uer. rel. I. On the several meanings of natura in uera rel., see, e.g., J. Lössl, Augustinus, De vera religione: Die wahre Religion, (Paderborn 2006), 77 n. 5.

88) E.g., uer. rel. 8; 9; Io (they seem to be the "carnales Christiani" invoked!); I 2; I6. 
substances, each with its prime source, which are at war with each other." 89 The immediately following sentences mention some basic tenets of the Manichaenans: God is the auctor of the things they take delight in; they hold that there are two souls in one body; the race of darkness is neither generated, nor created, ${ }^{90}$ nor brought forth, nor thrown down, but has its own life, earth, fetuses, and living beings, in sum its own kingdom and unbegotten origin; the race of darkness rebelled against God who, pressed by necessity, sent forth the good soul which is part of his own substance; through the commingling the enemy was bound and the world created.

The first protreptic ${ }^{11}$ section $(2 \mathrm{I}-44)$ is a brief history of salvation and presents a number of solutions to the pivotal Manichaean problem of the origin of evil. Here, time after time Manichaean doctrines are explicitly refuted. ${ }^{92}$ The second protreptic section (45-106) may be described as an ascent of the mind to God. ${ }^{33}$ Here, and in the epilogue (IO7-I I3), the Manichaean doctrines are mentioned less frequently. ${ }^{94}$

89) Ver. rel. I6: "Contra eos tamen potissimum est instituta, qui duas naturas uel substantias singulis principiis aduersus inuicem rebelles esse arbitrantur." Cf. retr. I, I3, I: "Maxime tamen contra duas naturas Manichaeorum liber hic loquitur."

90) In uer. rel. (cf., e.g., $2 \mathrm{I} ; 22$ ) facere seems to be equivalent to creare; for a demiurgical making A. prefers the verb fabricare (e.g., uer. rel. 2), though for instance in uer. rel. 3 he also states: "ab illo aeterno deo per eius veritatem fabricata." When referring to the M.'s creation myth, A. always uses the verb fabricare; see, e.g., c. Fort. 3.

91) For the protreptic character of uer. rel., see Lössl, De vera religione (see above, n. 87), 9f. 92) E.g., 2 I ("Nulla vita est, quae non sit ex deo, quia deus utique summa vita est et ipse fons vitae, nec aliqua vita, in quantum vita est, malum est"); 23 ("Hoc est totum quod dicitur malum, id est peccatum et poena peccati"); 26 ("solus deus est incommutabilis"); 27 ("Non autem recte negat peccasse animam, qui et paenitendo eam corrigi fatetur et veniam paenitenti dari et perseverantem in peccatis iusta dei lege damnari; ... ne hoc quidem dubitandum video habere animas liberum voluntatis arbitrium"); 32 ("nulla substantia malum est”); 34 (“... negat utrumque testamentum ab uno deo esse posse ... Si autem praecepta vitae movent, quod in vetere lege minora sunt, in evangelio maiora, et ideo putatur non ad unum deum utraque pertinere ..."); 38 ("nulla substantia malum est"); 40 ("Sed facillimum est exsecrari carnem, difficillimum autem non carnaliter sapere”).

93) F. Van Fleteren, 'Augustine's “De vera religione.” A New Approach,' Augustinianum I6 (I976) $475-497$.

94) E.g., 73 ("Non illic tibi [sc. Romanianus], non omino solis huius lumen occurret, sed lumen verum, quod illuminat omnem hominem venientem in hunc mundum [Io I,9], quod his oculis videri non potest"); 8I ("Ipse autem ordinis modus vivit in veritate perpetua nec mole vastus nec protractione volubilis, sed potentia supra omnes locos magnus, aeternitate supra omnia tempora immobilis, sine quo tamen nec ullius molis vastitas in unum redigi nec ullius temporis productio potest ab errore cohiberi et aliquid esse vel corpus, ut corpus 
The Profit of Believing-Augustine's first work written after his ordination (39I) addresses the Manichaean Honoratus, a friend of his youth. Once Augustine converted this pagan to Manichaeism, and here he tries to convert him to Catholicism. Though the work is not intended to be a clear-cut refutation of the Manichaeans ${ }^{95}$ - in actual fact it is a protreptic and apologetic work ${ }^{96}$ in which true Catholic faith is expounded and defended in order to win Honoratus_- it contains several important comments on them. Throughout the book they are judged to be "heretics," 97 which by implication means they are considered (and also believe themselves) to be Christians. ${ }^{98}$ Hence the figure of Christ is an important discussion topic (e.g., $3 \mathrm{I}-32$ ). The same goes for the biblical Scriptures: the Manichaeans "rend the Old Testament in pieces" (4), consider the writings of the New Testament as being corrupted "and falsified by persons who wished to combine the Law of the Jews with the Gospel" (7) and completely reject the New Testament book Acts because the Holy Spirit promised by the Lord came through Mani (7).

As regards the Manichaeans' claim that the Scriptures were corrupted, Augustine states he always thought this argument (uox) most weak, even at the time he was their Hearer, and that the same applied to Honoratus. ${ }^{99}$ Perhaps

sit, vel motus, ut motus sit. Ipsum est unum principale nec per finitum nec per infinitum crassum nec per finitum nec per infinitum mutabile"); 96 ("alii [deum esse] candorem lucis immensae per infinita spatia usquequaque porrectum ex una tamen parte quasi nigro quodam cuneo fissum duo adversa regna opinantes et talia rebus constitu entes principia cum suis phantasmatibus fabulati sunt"); 99 ("utrum oculi dei et manus et pedes et alia huius generis membra, quae in scripturis nominantur, ad visibilem formam humani corporis referenda sint ... proteruitas puerilis"); ro9 ("Non sit nobis religio cultus illius vitae, qua dicuntur arbores vivere").

95) Util. cred. 36: "nondum me Manichaeos coepisse refellere"; cf. retr. I, I 4,6.

96) For its protreptic and apologetic (and thus anti-Manichaean) character, see, e.g., A. Hoffmann, Augustins Schrift "De utilitate credendi." Eine Analyse, (Münster I997), 39-45; cf. idem, Augustinus De utilitate credendi ... (Fontes Christiani 9), (Freiburg I992), I4-I6.

97) Already at the very beginning of the book: "Si mihi, Honorate, unum atque idem videretur esse, haereticus, et credens haereticis homo ... quandoquidem haereticus est ...." Other explicit references in util. cred. 19.2 1.30-31.32.

98) Cf. util. cred. 30: “... ille haereticus (siquidem de his nobis sermo est, qui se christianos dici volunt) ...”; 3 I: "Quid, quod omnes haeretici Christo nos credere hortantur?”; “... profecto ut Christo credamus, agunt impudenter"; "Ego [a Manichaean heretic is speaking!] te doceo quid Christus praeceperit, cui credis"; 32: "Si autem Christo etiam credendum negant nisi indubitata ratio reddita fuerit, christiani non sunt"; "Hos vero quis ferat ad Christum se pertinere profiteri, qui nisi apertissimam rationem stultis de Deo protulerint, nihil credendum esse contendunt?"

99) Util. cred. 7: "Quae vox mihi semper quidem, etiam cum eos audirem, inualidissima uisa 
this indicates that Honoratus was among Augustine's close friends during the private interview with Faustus ${ }^{100}$ and that, by then, this topic was already discussed.

In a major endeavour to defend the Old Testament and make its writings acceptable, Augustine expounds a theory of the four-fold senses of Scripture ( $5 \mathrm{ff}$.). A considerable part of the work $\left(\mathrm{I}_{4}-35\right)$ is on fides and its relation to ratio, both according to the Catholic and the Manichaean point of view. Typical features of the Manichaeans, such as their question "unde sit malum," are referred to in Chapter 36 in particular. There, one also reads an exceptional invective at their outer appearence: "those men of bloodless bodies!" 101

In Chapter 2, for the first time the Manichaeans' claim of offering rational faith in stead of superstitio and all "terror of authority," and also their recurrent promise of "open and pure truth," are mentioned. In Chapter 3, Augustine recalls a typical saying of the Manichaeans in case a Hearer had left them: "The Light has made a passage through him." ${ }^{102}$ Accommodating himself somewhat to Manichaean parlance, Augustine says that he calls to witness "God who has his dwelling in pure souls." 103 He even states that once he also learnt some "truth" among the Manichaeans. ${ }^{104}$

The Two Souls - In comparison to most of the previous writings, this work (written c. 392) does not yield much information on the Manichaeans. A number of the usual themes are briefly mentioned, though sometimes with interesting details: the Manichaean Christians say that the sun and the moon and every light come from the true and good God (2), which light they confirm is from the Father of Christ (3); they preach that this light should be worshipped (3), and they say: "insofar as a thing shines, it is from God" (8); they use Gospel texts (9); they believe a feather has its brightness from God (Io); they teach that in the greatest evil, before the "commingling" (commixtio)

est; nec mihi soli, sed etiam tibi (nam bene memini) et nobis omnibus, qui paulo maiorem diligentiam in iudicando habere conabamur, quam turba credentium."

100) Another and perhaps even stronger indication may be found in util. cred. 20 : "quae mihi cunctatio in dies maior oboriebatur, ex quo illum hominem [sc. Faustus], cuius nobis aduentus, ut nosti, ad explicanda omnia quae nos mouebant, quasi de caelo promittebatur, audiui." For this interview, see conf. 5,6, I I.

101) Util cred. 36: "illi homines exsangues corporibus."

102) Util cred. 3: "Lumen per illum transitum fecit," i.e. the enlightened Hearer (cf. c. ep. Man. 5,6; 25,28) is now deserted by the Light, namely the true and saving message of the M. 103) Util cred. 13: "Testor, Honorate, conscientiam meam, et puris animis inhabitantem Deum ...."

104) Util cred. 36: "Ita quod apud eos uerum didiceram ...." 
of the two natures, there never was any good (I6); they affirm there is a divine lex and iudicium by which some souls are condemned (I7); they never denied that uenia peccatorum is granted whenever someone converted to God (I8).

The work's main theme, namely that-according to Augustine-Mani's followers held the theory that there are two animae in each human being, one soul being a part of the substance of God and the other a part of the substance of evil, has led to much controversy. Several scholars have questioned whether the Manichaeans held such a theory. ${ }^{105}$ I would like to refer, however, to parallels in Jewish and early Jewish-Christian writings such as the Manual of Discipline, the Testament of Judah, the Testament of Asher, the Shepherd of Hermas $^{106}$ and, moreover, to the rabbinic doctrine of the two yetsarim ${ }^{107}$ as close parallels and possible sources. ${ }^{108}$ Perhaps much difficulty is caused by terminology: Augustine's explicit speaking of two opposing animae is, up to now, not confirmed by original texts of the Manichaeans, but for instance in haer. 46 Augustine speaks of two mentes, ${ }^{109}$ and elsewhere he closely connects the Manichaeans' two souls theory with their postulation of two uoluntates in each human. ${ }^{110}$

105) E.g., F.C. Baur and H.-Ch. Puech. Cf. G.G. Stroumsa, 'The Two Souls' (I998), repr. in Stroumsa, Barbarian Philosophy. The Religious Revolution of Early Christianity, (Tübingen I999), 282-29I (283).

106) On concepts of the two spirits in these and other Jewish and Christian writings, cf. van Oort, Jerusalem and Babylon (see above, n. 37), $322 \mathrm{ff}$.

107) G.H. Cohen Stuart, The Struggle in Man between Good and Evil. An Inquiry into the Rabbinic Concept of Yezer Hara', (Kampen i 984).

108) The Pastor Hermae was well known in Manichaean circles: see, e.g., F.W.K. Müller, 'Eine Hermas-Stelle in manichäischer Version,' Sitzungsberichte der Preussischen Akademie der Wissenschaften I905, (Berlin I905), I077-1083; L. Cirillo, 'Le Pasteur d'Hermas dans la tradition manichéenne: à propos du fragment M 97 en pehlvi,' in: Aloïs Van Tongerloo o Søren Giversen (eds.), Manichaica Selecta. Studies presented to Professor Julien Ries at the occasion of his seventieth birthday, (Lovanii I 99I), 49-52. Moreover, Secundinus's speaking of spiritus uirtutum and spiritus uitiorum in $\$ 2$ of his Letter to A. seems to indicate knowledge of the Pastor Hermae.

109) Haer. 46, 19: "easque duas animas, uel duas mentes, unam bonam, alteram malam, in uno homine inter se habere conflictum, quando caro concupiscit aduersus spiritum, et spiritus aduersus carnem."

110) E.g., conf. 8, I0,22: “... seductores, qui cum duas uoluntates in deliberando animaduerterint, duas naturas duarum mentium esse asseuerant, unam bonam, alteram malam"; 8, I 0,24: "Iam ergo non dicant, cum duas uoluntates in homine uno aduersari sibi sentiunt, duas contrarias mentes, de duabus contrariis substantiis, et de duobus contrariis principiis contendere, unam bonam, alteram malam.” 
Against Fortunatus - In retrospect (retr. I, I 6), Augustine communicates that the public dispute with Fortunatus, "a presbyter of the Manichaeans who had lived for a considerable time in Hippo and had led so many astray," was on the issue of "whence is evil." Indeed, this pivotal Manichaean question was recurrently discussed, but in the Acta contra Fortunatum Manichaeum (392) many other topics are dealt with as well: the Manichaeans' concept of God; dualism; the soul; human existence; Christology; Scripture; and so on. The debate displays a certain lack of structure, though a constituent element is Fortunatus's well-defined statement of his belief (2). Moreover, the Manichaean priest appears to be well versed in quoting from the Gospels and the Letters of Paul. ${ }^{111}$ The two combatants present their intimate knowledge of Manichaean terminology in guarded terms; yet it is the recently ordained Catholic presbyter Augustine who in particular reveals a profound familiarity with texts of Mani as well. ${ }^{112}$ Fortunatus finally gives up and expresses his intention to take Augustine's questions to his maiores (37). Modern research rightly stresses the importance of this dispute in the development of Augustine's own set of beliefs. ${ }^{113}$ Besides, it may be questioned whether Augustine was, in fact, the debate's real winner. ${ }^{114}$

Against Adimantus - The work (as a rule dated c. 393) is directed against a number of disputationes of Mani's disciple Adimantus, who discussed the discrepancies between passages from the New Testament (the Gospels-specifically the Sermon on the Mount-and the corpus Paulinum) and certain passages from the Hebrew Bible (especially the Pentateuch). From Augustine's refutations here and in some of his sermons, ${ }^{115}$ one gets an impression of the biblical argument used in the Manichaean missionary practice amongst other Christians in particular. Time and again the "contradicting" passages are termed capitula (c. Adim. I.3.4. etc.), but often they are referred to as loci, sententiae and, sometimes, uerba as well. Their principal designation, however,

\footnotetext{
111) Texts from Matt. in I 4.2 I.22; from John in 3.2 I.32.33; from the corpus Paulininum in 7.16.17.19.21.26.

112) Van Oort, 'Heeding and Hiding' (see above, n. 4I); cf. idem, 'Index of Manichaean Terms and Concepts' in: François Decret \& Johannes van Oort, Acta contra Fortunatum Manichaeum (CFM, Series Latina 2), (Turnhout 2004), 9I-I I 2.

113) E.g., Malcolm E. Alflatt, 'The Development of the Idea of Involuntary Sin in St. Augustine,' Revue des Etudes Augustinienns 20 (I974) I I 3-I34; idem, 'The Responsibility for Involuntary Sin in Saint Augustine,' Recherches Augustiniennes Io (1975) I7 I-I 86.

114) Jason D. BeDuhn, 'Did Augustine Win His Debate with Fortunatus?,' in: Van den Berg a.o. (eds.), 'In Search of Truth' (see above, n. I 5), 463-479.

115) See van den Berg, Biblical Argument (see above, n. 37).
} 
seems to be capitula, capitulum in all probability being a technical term for a section of the Bible (cf., e.g., conf. 8,12,29) and also for its subsequent discussion (cf. Faustus's so-called Capitula). Subjects of discussion in c. Adim. are scriptural passages considered to be mutual contraria or aduersa: God created through himself (Gen. I, I-5) —God created through Christ (John I, I O; Col. I, I 5-I6); God rested (Gen. 2,2)—God works all the time (John 5, I7); God formed a wife for Adam (Gen. 2, I 8-24) — marriage should be renounced (Matt. I9,29 and parallels); ${ }^{116}$ and so on. In his sometimes rather extensive replies Augustine stresses the integral unity of the Old and New Testaments, and the identity of their God and revelation. The mainly exegetical work demonstrates the Manichaeans' impact upon essential elements of Augustine's biblical interpretation.

Against the Epistle of Manichaeus Called Fundamental-This book (end 396/early 397) is listed in retr. 2,2 as Augustine's second writing after his episcopal consecration. The brief notice in retr. states that only the principia of Mani's Letter have been refuted, "but for the other parts of it (sed in ceteris illius partibus) notes have been affixed (affixae) where it seemed good." This seems to be a clear reference to a codex with Augustine's annotations (on separate leaves? Or, rather, as marginal glosses? ${ }^{117}$ ) "affixed" to its pages. Perhaps this was the codex which also came to play a role in the debate with Felix, ${ }^{118}$ and which might have been in Augustine's possession for a long time. In retr. 2,2 Augustine further states that by his personal adnotationes the full contents of Mani's Letter was refuted, and that he would have been stimulated by these notes if he would ever have had time to write against the whole Letter. ${ }^{119}$

It is generally held that the word principia in retr. 2,2 refers to the "beginning" or some first parts of Mani's Letter, ${ }^{120}$ which view seems to have 116) C. Adim. I-3; see further van den Berg and his overview pp. I 50-I 5 I.
117) Cf. retr. 2, I 3 in regard to the Adnotationes in Iob: "Liber cuius est titulus Adnotationes
in Iob (...) redegerunt in unum corpus descriptas de frontibus codicis ...."
118) C. Fel. I. I 4-I 7 etc.
119) Retr. 2,2: "liber contra epistolam Manichaei quam uocant Fundamenti, principia eius sola redarguit; sed in ceteris illius partibus, adnotationes ubi uidebatur affixae sunt, quibus tota subuertitur, et quibus commouerer, si quando contra totam scribere uacauisset."

120) E.g., François Decret, 'Epistulam Manichaei quam uocant fundamenti (Contra-),' Augustinus-Lexikon, 2, (Basel I996-2002), I072 ("débuts"); among the many other testimonies, see, e.g., M. Jourjon in Bibliothèque Augustinienne I7, (Paris I961), 386 n. I ("début"; cf. ibid. 379 G. Bardy's translation of retr. 2,2: "débuts"), Roland Teske in his translation in The Works of Saint Augustine, vol. I/I9, The Manichaean Debate, (New York 2006), 227 and 233: "beginning," François Dolbeau, 'Un opuscule latin contre les Manichéens, 
influenced the reconstructions of its contents. ${ }^{121} \mathrm{With}$ reference to Augustine's just quoted remark in I I, I 3 and, above all, based on his actual discussion, one might infer that principia could indicate the Letter's main contents. In any case, in the sections of the work containing his refutation, Augustine confines himself to fundamental points such as Mani's claim to be an apostle of Jesus Christ (he emphasizes the unreasonableness of the Manichaeans' demand to believe this, because they promised knowledge of the truth rather than belief); Mani's idea that one side of the land of light faces the land of darkness (Augustine stresses its senselessness and objects to the idea that both God and his land of light as well as the land of darkness are corporeal); and Mani's description of the world of darkness (Augustine highlights its inconsistency).

Throughout the work the Manichaeans are challenged to defend Mani's sayings and, moreover, they are directly addressed: the freshly consecrated Catholic bishop is seeking their correction. ${ }^{122}$ Augustine refers to the fact that, in the past, he had discussed the Letter's contents with Mani's followers. ${ }^{123}$ When he was their Hearer, he also conversed with them about the fact that they preferred the festival of Mani's Bema to the Lord's Pascha; it is in this context that Augustine, once more in his anti-Manichaean oeuvre, explicitly states that the Manichaeans consider themselves to be Christians. ${ }^{124}$

Neither by its argument nor by its diction does Augustine's c. ep. Man. seem to have affected its target audience. The badly composed work gives

placé sous le nom d'Augustin,' Archiv für Religionsgeschichte 2 (2000) 244 ("le début") and Stein, Manichaei epistula (below, n. I 2 I), 6o n. 2. Indeed, principium in c. ep. Man. 6,7 and I I, I 3 denotes the beginning(s) of the Letter, i.e. its title $(6,7)$ and first fragments (I I, I 2I3). In I I, I3, however, A. clearly makes a distinction between the Letter's principium and its causa or, in other words, between its beginning(s) and real subject matter with which he is going to deal: "Et omnino quidquid in huius epistolae principio scriptum est, donec ueniatur ad causam, nolo reprehendere, ne in rebus minoribus multum operae consumatur. Iam ergo euidentissimam pollicitationem hominis [sc. Mani's] uideamus."

121) Erich Feldmann, Die "Epistula Fundamenti" der nordafrikanischen Manichäer. Versuch einer Rekonstruktion, (Altenberge 1987); M. Stein, Manichaei epistula fundamenti (Manichaica Latina 2), (Paderborn 2002).

122) See in particular c. ep. Man. I, I, with its full reference to 2 Tim 2,24-25. Cf., e.g., $c$. ep. Man.I. ; 4,5;43,49 for the M. as haeretici to be corrected.

123) E.g., c. ер. Man. 20,22: "Dicant ergo, ex alio latere, vel ex aliis lateribus, quid adiungebatur terrae lucis, si ex uno latere erat gens tenebrarum? Non dicunt: sed cum premuntur ut dicant, infinita dicunt esse alia latera terrae illius quam lucis vocant, id est, per infinita spatia distendi, et nullo fine cohiberi." Cf. 28,3 I and 32,35.

124) C. ep. Man. 8,9: "homines, qui se christianos dici uolunt." In demarcating contrast, A. in I 2, I 4 (cf., e.g., 4,5) labels himself a "catholicus christianus." 
the impression of notes on fundamental Manichaean themes, interspersed with several digressions. ${ }^{125}$ Philosophical ideas such as "what is, is good," 126 or proclaimed Catholic faith "that all the natures that God made and created, arranged in levels of excellence from the highest down to the lowest, are all good, but that some are better than others, and that they were made out of nothing"127 (in other words: once again creatio ex nibilo as the origin of a well-structured universe) will not have impressed the gnostic-Christian Manichaeans. Their myth told another tale and, apart from its quotes from Mani's Epistle, Augustine's volumen ${ }^{128}$ provides unique information on several intricacies of this myth. ${ }^{129}$

Against Faustus-Augustine's most comprehensive anti-Manichaean work (c. 400-404) is directed against the so-called Capitula of bishop Faustus. In retr. 2,7 Augustine specifies the character of both his and Faustus's work: "I wrote a bulky work (opus grande) against Faustus, a Manichaean who blasphemed the Law and the prophets and their God, and Christ's incarnation, and who stated that the Scriptures of the New Testament by which he is invalidated were falsified. I gave my responsiones to his uerba, which I put first. There are thirty-three disputationes or libri (why should I not call them that?)."

In Augustine's qualification of his answers as disputationes (only because of their size he is also speaking of libri), the term disputatio refers to his discussion of Faustus's disputationes, ${ }^{130}$ which were composed in answer to Catholic

\footnotetext{
125) E.g., c. ep. Man. I6,20-19,2 I, a long digression on the nature of the soul and memory.

126) c. ep. Man. 25,27: "in quantum esset, bonum esset"; cf., e.g., 3 I, 34.

127) c. ep. Man. 25,27. Cf., e.g., uer. rel.

128) C. ер. Man. 43,49.
}

129) See, e.g., c. ep. Man. 28,3 I (description of the five natures of darkness, with reference to other libri of the M.); 30,33-32,35 (further detailed analysis of the natures of darkness). In 25,28 A. refers to other litterae (i.e. written words, writings, treatises) of Mani's and says by implication that he is one of the few who are acquainted with them: "delere profecto Manichaei litteras non potestis: non dico alias quibus expressius ista descripsit-fortassis enim quia paucioribus notae sunt, minus periculi habere uideantur-sed istas ipsas, de quibus nunc agitur, Epistolae Fundamenti, quae fere omnibus qui apud uos illuminati uocantur solet esse notissima." The noun "litterae" is somewhat ambiguous in this context, which ambiguity seems to have led astray both M. Jourjon in Bibliothèque Augustinienne I7, (Paris I96I), 457 (“vous ne pouvez assurément détruire l'épitre de Mani, sans parler des autres épitres ...," with the note on p. 456) and François Decret in Augustinus-Lexikon 2, (Basel I996-2002), 1076-1077 (c. ep. Man. 25,28 is considered to refer to Letters of Mani). 130) For the term in reference to Faustus's work, see, e.g., c. Faustum 2 I,2: "in uestris disputationibus"; for another indication of his own answers as "disputationes," see, e.g., A.'s remark in I 2,2 where he even subdivides (part of) his answer as a tripartita disputatio. 
Christian questions (the same disputationes that are referred to as Faustus's capitula at the end of the book, and only there ${ }^{131}$ ). From their contents, which is each time quoted in full by Augustine before he discusses the matter in his own disputatio, it seems to become clear why Faustus's disputationes are classified as capitula: like in Adimantus's Disputationes, capitula in Faustus's work ${ }^{132}$ first of all seems to be the technical term for the scriptural passages (they are also referred to as sententiae ${ }^{133}$ ) which serve as the basis of the disputatio. After that, and by extension, capitulum also signifies the doctrine evolving from that discussion, or the discussion itself. Thus_-and in essence-Faustus's work consists of discussions of biblical passages and these disputationes, in conformity with their formal basis (i.e., the quoted biblical texts and even sections), also seem to be termed capitula. ${ }^{134}$ It is against this backdrop that one may also understand Faustus's explicit reference to Adimantus at the beginning of the volume in which his collected "Capitula" (indicated here as the "brief and polished responsa on account of the clever and cunning statements of those debating with us," i.e. Catholic Christians) came to Augustine's attention. ${ }^{135}$ There are close similarities between the two writings ${ }^{136}$ and Faustus appears to be building upon the literary work (in any case, so it seems, the Disputationes) of his illustrious predecessor. The main difference between Faustus's disputations

131) C. Faust. 33,9: "quapropter post omnes Fausti calumnias refutatas dumtaxat horum eius capitulorum, quibus hoc opere, quantum dominus adiuuare dignatus est, sufficienter, ut arbitror, prolixeque respondi." In view of the fact that only here Faustus's work is referred to as "capitula," I have my doubts in regard to the general practice to call his work "Capitula." There seems to be more reason to call it Disputationes.

132) Apart of many other instances, see, e.g., Faustus in c. Faust. I 6,2-6 (and A.'s use of the term in reply to Faustus in I6,26 in particular). Apparently other terms like propositio and argumentatio here refer to A.'s answer as being a disputatio as well.

133) See, e.g., c. Faust. I I, I for sententia and capitula.

134) Though there may be some similarity between Faustus's so-called Capitula and the Manichaean Kephalaia from Medinet Madi (in any case, both seem to belong to some form or another of erotapokriseis-literature), the contents of Faustus's work and the Kephalaia are very different and likewise (pace G. Wurst, "Bemerkungen zu Struktur und genus litterarium der Capitula des Faustus von Mileve," in: van Oort a.o. (eds.), Augustine and Manichaeism in the Latin West (see above, n. I7), 307-324) their (supposed) literary structure and genre. 135) C. Faust. I, 2: "Faustus dixit: 'satis superque in lucem iam traductis erroribus ac Iudaicae superstitionis simul et semichristianorum abunde detecta fallacia a doctissimo scilicet et solo nobis post beatum patrem nostrum Manichaeum studendo Adimanto non ab re uisum est, fratres carissimi, haec quoque breuia uobis et concinna responsa propter callidas et astutas conferentium nobiscum propositiones scribere ...."”

136) Useful overview of biblical texts and discussion topics in van den Berg, Biblical Argument (see above, n. 37), 97 n. I 86. 
and those of Adimantus seems to be that over time the focus had shifted from mere exegetical questions to more or less specific doctrinal issues. In essence, however, in both cases we are dealing with Manichaean biblical interpretation.

Based on this interpretation, in which in Marcion's footsteps the Old Testament is radically censured, topics of Faustus's work turn out to be Christ's incarnation and related Christological questions (c. Faust. 2, I; 3, I; 5, I-3; 7, I; $23, \mathrm{I}-4 ; 26, \mathrm{I}-2 ; 27, \mathrm{I} ; 28, \mathrm{I} ; 29, \mathrm{I})$, the incrimination and rejection of the Old Testament, its Law and prophets (4,I; 6,I; 8,I; 9, I; IO, I; I 2,I; I 3, I; I 4, I; I 5,I; I6,I-8; I7,I-2; I 8,I-3; I9,I-6;22,I-5) and the corruption of both Paul's Letters and the Gospels by Judaizing falsifiers (mainly I I, I; 3O, I-4; $3 \mathrm{I}, \mathrm{I}-3$ and $32, \mathrm{I}-7 ; 33, \mathrm{I}-3$ respectively). It should be noted that items like the Manichaeans' worship of the sun $(2 \mathrm{O}, \mathrm{I}-4)$ and the question of whether or not both of their two principia should be termed god (2 I, I) are expounded with essential reference to biblical texts as well. The same goes for the two remaining "capitula" dealing with the Manichaeans' concept of God, first in relation to his creation of "the new man" $(24, \mathrm{I})$, and then in regard to the question whether he has a limit or is limitless $(25, \mathrm{I})$.

The main characteristic of Augustine's extensive answers to each of Faustus's 32 "Capitula" is that all of his disputations are based upon biblical argument. It may be noted that Augustine not only deals with scriptural texts and related issues mentioned by Faustus, but that he also adduces a great number of other biblical texts and, for instance, important and often unique subject matter of the Manichaean myth, doctrines, and ethics. In his exegesis he time after time stresses the unity of the Old Testament; the symbolic-prophetic meaning of stories like those of the patriarchs, and a Jewish rite such as circumcision; the Christocentric character of the Old Testament and its fulfillment in the New Testament; the person of Jesus Christ being both divine and human, really incarnated, crucified, and resurrected.

Trying to fathom the richness of the very extensive book for nearly all aspects of Augustine's theology, while at the same time outlining the significance of its anti-Manichaean stance, is still a daunting task for future research. The same goes for the many new and intriguing statements regarding the Manichaeans and their doctrines. In this work Augustine does not restrain himself but (as far as I can see) frankly displays his knowledge. In addition to many details of the myth typical of the Manichaeans, ${ }^{137}$ he recurrently and rather extensively

137) Among many other passages, see, e.g., c. Faust. 2,3.4.5; I 3,6; $22,22$. 
deals with their doctrine of the globus (2,5.6; 5,7; 8,2 etc.); their Christology in general and the figure of Iesus patibilis in particular (20, I I; cf. Faustus in 20,2); the differences between the very strict ascetically living Mattarii and the other Elect $(5,5)$; the Manichaean concept of Trinity (e.g., 20,7; cf. Faustus in 20,2); the Manichaeans' use of impressive books, "those parchments and fancy covers made from beautiful leather" and placed on "your dinner tables" $(\mathrm{r} 3, \mathrm{I} 8)$. Apart from clear references to, or even quotations from Mani's Epistula fundamenti (e.g., 21,16;22,22 ${ }^{138}$ ), and an explicit mention of his Thesaurus $(\mathrm{I} 5,4)$, a number of impressive passages are recalled from a so-called Amatorium canticum (1 5,5-6), perhaps a song of the Elect accompanying their sacred meal. ${ }^{139}$

Against Felix - The work comprises the acts of the public debate between Augustine and doctor Felix (Hippo, 4 and I 2 Dec. 404). After five of Mani's books in Felix's possession had been confiscated, he declared himself ready to discuss their contents with Augustine; or to be burnt with them (I, I I I ; 2, I). ${ }^{140}$ Although, during the debate, Felix more than once asked for his five auctores, the confiscated books were not returned to him; in stead of these codices other books (and all of these procured by Augustine) played a conspicious part in the debate: first a codex comprising Mani's Epistula fundamenti ( $\mathrm{I}, \mathrm{I}$ ff.); after that a codex containing the Gospel of Luke $(I, 2)$, and a codex containing his canonical Acts $(\mathrm{I}, 2)$; later on in any case a codex with the Pauline letters ( 1,7 ff.). Many other scriptural (i.e., mainly New Testament) quotes seem to have been made from memory, both by Augustine and Felix. Two curious citations, one from Mani's Thesaurus $(2,5)$, and the other from "the Acts written by Leutius" $(2,6)^{141}$ —both being adduced in support of a Manichaean doctrine of "free choice" — come from the lips and, evidently, the memory of Augustine.

The main discussion topics of the first day are occasioned by passages read aloud from Mani's Epistula fundamenti: Mani's claim to be the promised Para-

138) Curiously, the last reference is lacking in Feldmann, Epistula fundamenti (see above, n. I 2 I), while the first one is only referred to in passing (I3 I n. 86) as being a "freiere, offenbar aus dem Gedächtnis gemachte Wiedergabe."

139) See, e.g., Reinhold Merkelbach, Mani und sein Religionssystem, (Opladen I 986), 55-56, who also adds a brief passage from $c$. Faust. I 5,9.

140) On this Felix, see also retr. 2,8; ep. 79; Possid. uita Aug. I6.

141) For these Acts, see, e.g., Knut Schäferdiek, 'Die Leukios Charinos zugeschriebene manichäische Sammlung apokrypher Apostelgeschichten,' in: Wilhelm Schneemelcher (ed.), Neutestamentliche Apokryphen in deutscher Übersetzung, II, (Tübingen I997), 8 I93. 
clete; his teaching of initium, medium, finis; his opinion that God's "splendid kingdoms" are "founded upon the bright and blessed land"; the ensuing question whether these kingdoms are made (facta) or begot (genita) by God, or are coeternal (coeterna) with him; and, moreover, whether "the unborn Father," "the unborn land," and "the unborn air" are of one and the same substance ( $\mathrm{I}, \mathrm{I}-\mathrm{I} 8$ ). The beginning of the clear blasphemies (apertae blasphemiae) Augustine finds in the episode in the Epistle where God's reaction to the attack of "the race of darkness" is described $(\mathrm{I}, \mathrm{I} 9)$. Here the Nebridian argument ${ }^{142}$ is employed in full $(\mathrm{I}, \mathrm{I})$ ). Felix askes for a delay "up to the day after the Lord's Day"143 and signs the proceedings as "Felix Christianus, cultor legis Manichaei" $(\mathrm{I}, 20)$.

In the second session Augustine first repeats the Nebridian argument in full $(2, \mathrm{I})$ and, moreover, he later returns to it repeatedly $(2,3.7 .8$.9. I I. I 3 ; see also Felix' abjuration in 2,22). Other discussion topics include Mani's doctrine of the two naturae $(2,2)$; the question of liberum arbitrium (2,3-6.8. I2); the shameful way in which God is purified (in other words: Mani's doctrine of the seduction of the archons, 2,7; cf. 2,13); and the concept of the globus (2,78.I 5.I6). In regard to Mani's concept of an eternal globus, Felix adduces an important nuance: the non-purified parts of God are not damned (damnata), but according to Mani "they were placed for custody (ad custodiam) of the nation of darkness" $(2, \mathrm{I} 6)$. One may suppose that Felix here is referring to (and perhaps even quoting from) one of Mani's writings. The rest of the debate mainly focuses on the question whether or not the human soul is ex Deo or de Deo (I7-I 8.20.2I). In this context, Augustine once again stresses his doctrines of creatio ex nibilo and liberum arbitrium (19-20).

Felix finally gives up, but not without stating his mental reservation: "God sees whether I do it (i.e. anathematize Mani) from my heart. For a human being cannot see that" (22). One gets the impression that, out of fear for the civil authorities, he quickly signed the charta, thus anathematizing "Mani,

142) The Nebridian argument meant much to A. Briefly stated, it is the problem originally raised by Nebridius, A.'s friend already in Carthage and onetime following Manichaean opinions (cf. conf. $7,2,3 ; 9,3,6$ ) that seems to contradict the M.'s confession of both God's incorruptibilty (and, thus, impassibility) and his being almighty: If God could not be harmed by evil, why did he consign part of himself to combat with evil? In different turns of phrase, the Nebridian Conundrum is time and again repeated by A.; cf. 'Final remarks' and $\mathrm{n}$. $\mathrm{I} 74$ below.

143) One may conclude from this indication that, in Roman Africa, the Manichaeans observed Sunday as "the Lord's Day" (dies dominicus). The same is attested in the Coptic Manichaean writings by the Greek loan word "kuriakē." 
his teaching, and the seductive spirit that was in him," and at the same time explicitly consenting to the Nebridian argument and rejecting the story of the seduction of the archons $(2,22)$. Augustine's disciple and first biographer Possidius concluded that Felix "ad nostram conuersus est fidem" (uita Aug. I 6,4), but only in reference to the just outlined acta ecclesiastica. It seems telling that Augustine, neither in his retr. nor elsewhere, ever made such a claim.

The Nature of Good -At first sight, this anti-Manichaean work (written perhaps c. 404/5) contains little that Augustine had not said elsewhere. However, several things Manichaean are expressed without reticence and, moreover, Augustine presents a long and unique passage from Mani's Thesaurus (44), and also four citations from his Epistula Fundamenti (42.46).

As a rule the work is considered to consist of two main parts. In the first one Augustine explains the Catholic and, after that, refutes the Manichaean view of God and evil. This is done firstly by philosophical-mainly logicalargumentation $(\mathrm{I}-23)$, and then by appeal to Scripture, especially the writings of Paul (24-40). The second part, comprising only the book's final paragraphs $(4 \mathrm{I}-47)$, is a refutation of the Manichaean doctrine of two principles (4I-44) and, to some extent, a reprise of former allegations (such as in mor. 2) against the Manichaeans' immorality (45-47).

In Chapter I8, Augustine correctly points out that Mani referred to the substance of evil as "Hyle," 144 and that he considered this byle (evil matter, characterized by its random motion ${ }^{145}$ ) to be the formatrix of bodies. Because of Hyle's ability to fashion and create bodies, Augustine feels himself entitled to consider it "another God."

The book's second part starts with a detailed description of the qualities of the Manichaean kingdom of darkness and its inhabitants (4I). On close reading the same Chapter 4I also provides very specific details of their Christology: in regard to the nature of God conquered by darkness, the Manichaeans teach that it is raised by Christ; that Christ cures it; awakens it from forgetfulness; teaches it wisdom; restores it; sets it free; helps it out; stirs it up; enlightens it;

144) See also, for instance, c. Faust. 20,3.I4-I 5; 2 I, I.4.9-I I.I 3.I 4. I6; 22,22. From references to original writings of Mani, for instance made by Titus of Bostra and Severus of Antioch, we know that Mani himself used the Greek word for his concept. The word (and concept) is prevalent in the Coptic Manichaean writings as well; see Sarah Clackson and others, Dictionary of Manichaean Texts, volume I, Texts from the Roman Empire (CFM, Subsidia II), (Turnhout I 998), 85 .

145) L. Troje, 'Zum Begriff ATAKTO $\Sigma$ KINH $\Sigma \mathrm{I} \Sigma$ bei Platon und Mani,' Museum Helveticum s (I948) 96-I I 5 . 
relieves it; corrects it by his commandments; cleanses it; promises peace to it; poses a limit to it by his Law; re-forms it; and corrects it. "The Manichaeans say that Christ bestows all of this (...) on the very nature, the very substance of God, which is identical with God." 146

Very specific as well is Augustine's speaking of the Manichaean globus tenebrarum or globus horribilis (42-43), his reasoning that even Mani held some doctrine of free will (42), ${ }^{147}$ and his extensive discussion of the so-called "seduction of the archons" episode in Mani's myth on the basis of two lengthy quotes from the Thesaurus and the Epistula fundamenti (44-47). Evidently, Augustine wants to drive home his view that-in essence-the heretical opinion of the Manichaeans is a "monstrous wickedness" because, according to their myth, "a part of God is bound through the coitus of males and females, a part they say that they set free and purify by eating." The logical consequence is, so Augustine, that they release and purify this part of God "not only from bread and vegetables and fruit, which are the only things they are seen to eat publicly, but also from that seed that can hold it fettered if it is received in the womb of a female." ${ }^{148}$ As a kind of prelude to his report in haer. 46 (see below), Augustine continues by telling what he has heard from a Catholic Christian in Rome: both in Paphlagonia and in Gaul Manichaeans, in a public hearing, confessed that, incited by the just quoted passage from the seventh book of Mani's Thesaurus, they do indeed follow this practice ${ }^{149}$ At the end of nat. $b$. Augustine prays

146) Future research may compare this Christian soteriology with, for instance, the remarks made by Fortunatus in his disputation with A., but with several other traces in A.'s works as well.

147) Cf. c. Fel. 2,5, though there A.'s reference is to Mani's Thesaurus; here, however, to his Epistula fundamenti.

148) Nat. b. 47: "O monstrum scelestum! (...) Hoc saltem attendant miseri decepti et errore mortifero uenenati, quia si per coitum masculorum et feminarum ligatur pars Dei, quam se manducando soluere et purgare profitentur, cogit eos huius tam nefandi erroris necessitas, ut non solum de pane et oleribus et pomis, quae sola uidentur in manifesto accipere, sed inde etiam soluant et purgent partem Dei, unde per concubitum potest, si feminae utero concepta fuerit, colligari."

149) Nat. b. 47: "Hoc se facere quidam confessi esse in publico iudicio perhibentur, non tantum in Paphlagonia, sed etiam in Gallia, sicut a quodam Romae christiano catholico audiui: et cum interrogarentur, cuius auctoritate scripturae ista facerent, hoc de Thesauro suo prodidisse, quod paulo ante commemoraui." As a matter of fact, part of the sentence might be translated and interpreted otherwise, sc. that A. had heard that M. in Paphlagonia followed this practice (in that case he might have read this in one of the writings or letters of Basilius the Great) and that from a certain Catholic Christian in/from Rome he heard of this practice in Gaul. 
that God may set free the Manichaeans from their "execrable and extremely horrible error." 150

Against Secundinus - The work, originally a letter written in answer to a letter from the Roman Manichaean Secundinus, is listed in Augustine's retr. 2, Io as the last one of his anti-Manichaean writings. It is usually dated sometime after 404. Curiously, Augustine in the retr. also declares $c$. Sec. his favourite anti-Manichaean work. Perhaps this preference is the result of the fact that here all previous anti-Manichaean themes are present in some form or another: the ominipotent God created all things and made them good; Catholic Christology is contrasted to Manichaean "docetic" Christology; evil is not a substance; the consent to evil is not a substance either; the Manichaean God is considered to be corruptible; etc. In addition, more than elsewhere Augustine's argument turns out to be based on an (in the meantime considerably improved) exegesis of Old Testament and, in particular, New Testament texts. ${ }^{151}$

The question of whether or not Secundinus and Augustine had some personal acquaintance with each other is rather complicated. In retr. 2, I o Augustine explicitly denies that he knew Secundinus personally ("quem ne facie quidem noueram"), but it is also here that he classifies Secundinus as a Hearer (while this status is clear neither from his letter, nor from Augustine's extensive answer). In his own letter-which is a prime document among the Latin Manichaean documents-Secundinus, after having referred to a number of Old Testament texts and stories, claims to know that Augustine "always hated these things" (Sec. 3: "noui ego te haec semper odio habuisse"). This, however, might refer to Secundinus's reading of (some passages) of the conf., ${ }^{152}$ and not to some meeting of Augustine in Rome. Moreover, in his Letter Secundinus claims to have read some of Augustine's writings (Sec. 3: "legit enim aliquanta ... reuerendae tuae dignationis scripta").

Secundinus's explicit reference to the spiritus uirtuum and the spiritus uitiorum seems to indicate his acquaintance with the Shepherd of Hermas, ${ }^{153}$ and the same may go for his clear statement that, after a soul's second penance, "it will

150) Nat. b. 48: "praesta nobis, dona nobis, ut per nostrum ministerium, quo exsecrabilem et nimis horribilem hunc errorem redargui uoluisti, sicut iam multi liberati sunt, et alii liberentur."

151) On Secundinus's exegesis: Johannes van Oort, 'Secundini Manichaei Epistula: Roman Manichaean 'Biblical' Argument in the Age of Augustine,' Augustine and Manichaeism in the Latin West (see above, n. I7), I6I-I73.

152) Cf., e.g., A.'s remarks in conf. 6,5,8 ("iam enim absurditatem, quae me in illis litteris solebat offendere"); 6,4,6; 6, I I , I 8 .

153) Cf. above, n. Io8. 
find the author of mercies ready to pardon" (Sec. 2). Like the former Hearer Augustine, Secundinus bears witness to a thorough acquaince with writings of Mani. ${ }^{154}$

In his answer, Augustine boasts that he is able "to recite innumerable passages from the writings of Mani" (c. Sec. 3). He also exhorts Secundinus "to read the Scriptures" ( 5 ). Augustine has reason to suppose that Secundinus will easily recognize his quote from Col. (7), and he once addresses him with the exclusive Christian term "frater" (6). Induced by Secundinus's eschatological warnings (they are mainly based on Matt. 25, a central chapter in Mani's own eschatology; ${ }^{155}$ Sec. 2), Augustine rather extensively discusses the Manichaean concept of the eternal globus (I0.20.24). In this context, and as a real insider, he remarks that the Manichaeans maintain the incorruptibility of the body, but only for those eternally damned in the globus (Io).

Both letters contain many exhortations and invitations to join the rival one's Christian community. Secundinus for instance writes to Augustine: "Set aside human glory if you wish to please Christ. Renew Paul for our times" ("temporibus nostris renoua Paulum": Sec. 5). Augustine concludes his work with remarks such as "cross over to the Catholic Church and faith" and "Believe this, understand this" (26).

Heresies-Though as a matter of fact haer. (c. 428-430) is not an antiManichaean work, its Chapter 46 is briefly discussed here because it contains Augustine's only comprehensive overview of Manichaeism. Moreover, both the inception of the work (see the letters to and from the book's addressee Quodvultdeus, ep. 22 I-224), and its contents clearly show the Manichaeans' central importance to Augustine even near the end of his life.

A certain Theodosius, formerly a Manichaean but now a Catholic Christian, had exposed some Manichaeans in Carthage. ${ }^{156}$ Haer. 46,9-10 supplies further information about Theodosius's disclosure, which deals with some sort of human semen eucharist amongst the Manichaeans. Curiously, it is this item which Augustine frequently and since his earliest anti-Manichaean works ${ }^{157}$ has alluded to as being the real consequence of the most offensive part of their myth (sc. the so-called "Seduction of the Archons"). From gesta episcopalia

154) E.g., Sec. I: "hoc ipse testatur Manichaeus" and 6: "de saeculo nouo quod idem memorat."

155) See, e.g., Nils Arne Pedersen, Studies in The Sermon on the Great War, (Aarhus I996); cf. idem, Manichaean Homilies (see above, n. I4), 7-42.

156) Ep. 222,3.

157) E.g., mor. 2,66; c. Fort. 3; cf. nat. b. 47. 
Quodvultdeus sent him, and from other sources, ${ }^{158}$ Augustine saw confirmed what he did suspect since decades. ${ }^{159}$ Haer. 46 , Io also provides information on the claim that such acts are only performed by the Catharistae, a certain branch of the Manichaeans, but Augustine extensively repeats his view that such a rite is the consequence of their myth.

The other sections of haer. 46 provide a fairly complete ${ }^{160}$ summary of the religion Augustine knew so well: the Manichaeans' origin from "a certain Persian called Manis" or Man(n)ichaeus (haer. I); ${ }^{161}$ Mani's doctrine of two principles, natures, or substances (2); the Manichaeans' doctrine that God and the good souls are of one and the same nature (3); their doctrine of the origin of the world (4); the purgation of good from evil in which their Elect take an active part (5); their belief that the purified portion of the good returns to the kingdom of God by means of the moon and the sun, vessels made from the pure substance of God (6); their detailed doctrine of five elements of darkness and five elements of good (7); their opinion that the holy powers in the sun and the moon change themselves into males to attract females of the race of darkness, and into females to attract males, so that through their concupiscentia the imprisoned light will escape (8); the practice of the Manichaeans not to eat meat and to abstain even from eggs; and their practice not to drink milk or wine (I I); their doctrine of metempsychosis and of life in trees and plants, and its ethical consequences (I2); their view that conception and birth are to be avoided (I3); their view that Adam and Eve stem from the princes of darkness, whose father Saclas had devoured the children of all his associates (I 4); their opinion that the biblical serpent was Christ, who opened the eyes of knowledge of Adam and Eve; that Christ came to liberate souls, not bodies; and that he did not come in real flesh, but feigned not only death but also resurrection (I 5); their doctrine that Manichaeus was the Paraclete; that he had twelve disciples; that the twelve magistri ordinate seventy-two bishops; and that the bishops ordinate the priests and also have deacons (I 6); their view that baptism in water grants no salvation (I7); their custom to pray towards

158) Johannes van Oort, 'Mani and Manichaeism in Augustine's De haeresibus,' in Ronald E. Emmerick a.o. (eds.), Studia Manichaica, (Berlin 2000) (BBAW, Berichte und Abhandlungen, Sonderband 4) 45I-463, esp. $452 \mathrm{ff}$. and n. I 8.

159) Curious parallels to the whole story in, e.g., s. I6,4 of Leo Magnus; cf. Hendrik Gerhard Schipper \& Johannes van Oort, St. Leo the Great, Sermons and Letters against the Manichaeans (CFM, Series Latina I), (Turnhout 2000), I-2; 26-27.

160) Haer. 46, 2: “... multa fabulantur, quae cuncta intexere huic operi nimis longum est." 161) An analysis of this first paragraph in particular in van Oort, "Mani and Manichaeism in Augustine's De haeresibus' (see above, n. I 58 ). 
the sun and the moon and to stand while praying (I8); their doctrine that sin originates from the evil substance; and their view that two animae or mentes are in conflict in man, a conflict which will never be resolved; and finally their belief that the substance of evil will live in the globus as its eternal prison (I9).

In many of Augustine's other works, ${ }^{162}$ sermons, ${ }^{163}$ and letters, ${ }^{164}$ the Manichaeans play a significant role as well. Further analysis of these writings - and perhaps the identification of these and other works with some still puzzling titles in the list of Augustine's anti-Manichaean writings in the well-known Indiculum ${ }^{165}$ — may be a key challenge in future research.

\section{Conclusions}

From Augustine's oeuvre a whole range of essential data concerning Mani and his Church can be gathered. Thus, among many other things, Augustine provides information on the name of Mani (e.g., c. Faust. I9,22; haer. 46, I) and his provenance (e.g., c. Faust. 28,2.4); on his claim to be an "apostle of Jesus Christ" (e.g., c. ep. Man. 5; c. Fel. I, I; c. Faust. I 3,4); on the Manichaeans' doctrine of two opposed natures or substances (e.g., uera rel. I6; haer. 46,2); on the qualities of the supreme good God (e.g., mor. 2,3.I I-I 2; c. Fort. 3), his possession of wisdom and vital powers (e.g., c. ep. Man. I3), his splendid kingdom and its twelve eons (c. Faust. I 5,5; cf. c. ep. Man. I 3, I6); on the preexistent and eternal kingdom of darkness (e.g., cont. 9); on Hyle as the supreme evil (c. Faust. 20,3.I 4-I 5; 2 I, I.4.9-I I.I3.I 4.I6; 22,22; cf. nat. b. I 8) which reigns in the kingdom of darkness (e.g., c. Faust. 2 I, I 4); on the five elements

162) Like, e.g., the major works conf. (cf. van Oort, 'Manichaeism and Anti-Manichaeism in Augustine's Confessiones,' above n. I7 and, following this line of research, A. Kotzé, 'Reading Psalm 4 to the Manicheans,' Vigiliae Christianae 55 (200I) I I9-I36; eadem, Augustine's "Confessions." Communicative Purpose and Audience (Supplements to Vigiliae Christianae 7I), (Leiden-Boston 2004), esp. 97-I I 5.197-247; ead., "The "Anti-Manichaean" Passage in Confessions 3 and its "Manichaean Audience," Vigiliae Christianae 62 (2008) I 87-200) and ciu. (cf. van Oort, 'Manichaeism in Augustine's De ciuitate Dei,' above, n. 5 I). But see also, among many other testimonies, e.g., c. adu. leg. I, I; agon. 4; cont. I 4. I 8.22.24.26c. ep. Pel. 3,3 f.; c. Iul. I, 5. I 2 ff. etc.; c. Iul. imp. I, I ff.; diu. qu. I, I6; nupt. 2,3,7.8 ff.

163) Like, e.g., s. I and I 2 ; en. in Ps. 25 and I 40; s. Mai 95.

164) E.g., ep. 36,27.29; 55,6; 236; I65, I; I 66,7.

165) Cf. the identification of an "Epistula ad Honoratum" classified in the Indiculum under "Contra Manichaeos" with ep. I 40 in: I. Bochet, 'Une nouvelle lecture du Liber ad Honoratum d'Augustin (= epist. I 40)', Revue des Études Augustiniennes 45 (I999) 335-35 I. 
of darkness (e.g., mor. 2, I4; c. ep. Man. 28; haer. 46,7); on the "substance of evil" or "race of darkness" that waged war against God (e.g., agon. 4; cont. I4); on the emanation of Primal Man (Homo Primus) (e.g., c. Faust. 5,4; I I, 3) who plunged his five elements into the nation of darkness in order to take them captive (e.g., c. Faust. 2,3-4); on the defeat of Primal Man (e.g., ibid.); on the emanation of the "Powerful Spirit" (Spiritus Potens) who conquered the powers of evil, liberated Primal Man, and created the world out of the mixture of the five good and the five evil elements (e.g., c. Faust. 20,9; cf., e.g., mor. 2,60; uer. rel. I6; agon. 4). Et cetera. In addition to the texts just mentioned, one may particularly refer to mor. and haer. 46 to learn more about the Manichaeans' ethic, cult, and the structure of their Church.

It is difficult to find fundamental aspects of the Manichaean myth, ethic, cult, and Church organization which are not mentioned in some form or another by Augustine. Above, in the overview and analysis of his anti-Manichaean writings several aspects have been indicated. In terms of the amount of detail his $c$. Faust. stands out, but there is no reason to suppose that Augustine, in order to refute Faustus, first embarked on an intensive study of other Manichaean writings. Apart from the new "Capitula" of Faustus, there seems to have been no recent investigation of Manichaean texts, but—as suggested by Augustine's significant remark "Do you not remember?" when introducing passages from the Amatorium canticum ${ }^{166}$ — the issues raised by him give the impression of belonging to his standard knowledge and appear to be recalled from memory. ${ }^{167}$ Moreover, although Augustine is always writing on the Manichaeans in a very polemical context, he does not appear to intentionally provide false information: even the curious case described in haer. 46,9-10 may deal with reality and not merely with polemics. ${ }^{168}$

166) C. Faust. I 5, 5 ff.; see above.

167) See above, in the analysis of Against Felix, on the sudden reminder in the dispute with Felix (c. Fel. 2,5) that Mani, in his Thesaurus, has a doctrine of free will.

168) I do not agree here with, for instance, Alfaric, Evolution intellectuelle (see above, n. 3), I65 n. I, and therefore do not consider this story as being "légendaire." Some sort of sperma eucharist seems to have been well known in certain "gnostic" circles (see, e.g., Hans Leisegang, Die Gnosis, Leipzig ${ }^{4}$ I955, I91-195; cf. Kurt Rudolph, Die Gnosis, (Göttingen I 977), 4IO n. 93), but is also attested for certain currents of the Bon religion influenced by Manichaeism (see, e.g., Siegbert Hummel, 'Manichäisches in der tibetischen Bon-Religion,' Manichaean Studies Newsletter I990/I, 26). Ferdinand Christian Bauer, in his pioneering study Das manichäische Religionssystem, (Tübingen I83 I) (repr. Göttingen I928), 280 and 289 , also takes A.'s description as referring to real practice. 


\section{Manichaean Influences on Augustine?}

The question of permanent Manichaean influences on Augustine was already raised during his lifetime. Megalius of Calama, the primate of Numidia, at first refused to ordain him an auxiliary bishop of Hippo because of his Manichaean past. ${ }^{169}$ Subsequent charges of Manichaeism coming from the Donatist camp seem to have been fuelled by the conf. ${ }^{170}$ In the last long decade of Augustine's life the "Pelagian" Julian of Eclanum time and again repeated his accusations of Manichaeism. ${ }^{171}$ Moreover, this Catholic bishop even managed to produce a new letter of Mani, while at the same time indicating striking parallels between Mani's and Augustine's doctrines of concupiscence and original sin. ${ }^{172}$ It should be noted that Julian was not merely uttering charges, but had a more than superficial knowledge of the Manichaean doctrines. ${ }^{173}$

In more recent times a whole plethora of scholars have made mention of persistent Manichaean influences on Augustine. Here, apart from some authoritative handbooks, reference can only be made to some of the main studies of those specialized in both Augustine and Manichaeism.

Frequently Augustine's articulation of "dualism" has been evaluated as a permanent relic of his Manichaean past; ${ }^{174}$ besides, several researchers specif-

169) Cf. c. litt. Pet. 3, I6, I9; Cresc. 3,80,92.

170) See, e.g., Courcelle, Recherches (see above, n. 33), 238-245; W.H.C. Frend, 'Manichaeism in the Struggle between Saint Augustine and Petilian of Constantine,' Augustinus Magister, 2, (Paris I954), 859-866.

171) At least from c. 4I 8 onwards, culminating in remarks such as "Si mutabit Aethiops pellam suam aut pardus uarietatem, ita et tu a Manichaeorum mysteriis elueris" (c. Iul. imp. $4,42)$.

172) C. Iul. imp. 3, I66-2 I6 (cf. 4, I09); fragments of the Letter quoted 3, I72-1 87.

173) See, e.g., his more or less clear references to Mani's Fundamental Letter and its doctrines in c. Iul. imp. 3, I86; 4, I08. I09.I20; 5,25; 6,8. See for the wider context, e.g., Mathijs Lamberigts, 'Was Augustine a Manichaean? The Assessment of Julian of Aeclanum,' in: Augustine and Manichaeism in the Latin West (see above, n. I7), I I 3-I 36, esp. I I 7-I 20 for Julian's (though perhaps underestimated) knowledge of Manichaeism. Evaluating the Letter to Menoch as a genuine letter of Mani may rather radically change the picture.

174) E.g., Adolf von Harnack, Lehrbuch der Dogmengeschichte, III, (Tübingen ${ }^{4}$ I 9 Io (repr. Darmstadt I964)), 2 I 7 f.; Wilhelm Windelband, Lehrbuch der Geschichte der Philosophie, hrsg. von H. Heimsoeth, Tübingen I95 $7^{15}$, 245; cf. also Alfred Adam, Lehrbuch der Dogmengeschichte, I, (Gütersloh I970), 290, 30 I; Wilhelm Geerlings, Christus Exemplum. Studien zur Christologie und Christusverkündigung Augustins, (Tübingen 1978), 256. Dietrich Ritschl, 'Die Last des augustinischen Erbes', in: Parrhesia. Karl Barth zum achtzigsten Geburtstag, (Zürich I966), 474 rather typically asserts that A.'s doctrine of predestination and his ecclesiology contains "deutlich dualistisch-manichäische Elemente." 
ically refer to his antithetical doctrine of two ciuitates. ${ }^{175}$ His description of the terrena ciuitas in ciu. I I,33 is singled out as being directly inspired by Manichaeism. ${ }^{176}$ In regard to the conf. it has been remarked that its prevailing tone is gnostic-Manichaean. ${ }^{177}$ More specifically, some have referred to the central place of the act of confession in Mani's Church as the main model of the conf. and even to specific parallels with Manichaean confessional texts. ${ }^{178}$ Already Julian stated that, in fact, Augustine considered the sexual instinct as being of diabolic origin, while branding this opinion as a Manichaean relic. ${ }^{179}$ One may consider this as a distortion of Augustine's real view, ${ }^{180}$ but time and again, and based upon a great variety of texts, his persistent negative evaluation of sexual concupiscence and its role in the transmission of original sin has been pointed out as being in remarkable conformity with Manichaean opinions. ${ }^{181}$ It should be noted, however, that certain elements in both the doctrines

175) E.g., Alfaric, Évolution intellectuelle (see above, n. 3), I 23; Richard Reitzenstein, 'Augustin als antiker und mittelalterlicher Mensch,' Vorträge der Bibliothek Warburg, II, I, (Leipzig-Berlin 1924), 34-35; Francis Crawford Burkitt, The Religion of the Manichees, (Cambridge I925), I I; Alfred Adam, 'Der manichäische Ursprung der Lehre von den zwei Reichen bei Augustin,' Theologische Literaturzeitung 77 (I952) 385-390 (repr. in idem, Sprache und Dogma, (Gütersloh I969), I33-I40); Ekkehard Mühlenberg, 'Dogma und Lehre im Abendland: Von Augustin bis Anselm von Canterbury, in: Carl Andresen a.o. (eds.), Handbuch der Dogmen- und Theologiegeschichte, I, (Göttingen I999), 440.

176) E.g., Burkitt, Religion of the Manichees (see above, n. 175), I02-I03; Adam, Dogmengeschichte (see above, n. I74), I, 295. Cf. van Oort, Jerusalem and Babylon (see above, n. 37), 223, with reference to the Manichaean Kephalaia. See also van Oort, ibidem, 224 for the parallels in the concept of libido dominandi in ciu. I 4,28 and Kephalaia (ed. Polotsky, above n. I 2), p. 33,5-8, and, e.g., ibid. for the parallel divison of history into three times. 177) E.g., Adam, Dogmengeschichte (see above, n. I74), I, 290.

178) E.g., Alfred Adam, 'Das Fortwirken des Manichäismus bei Augustin,' Zeitschrift für Kirchengeschichte 69 (I958) I-25 (= idem, Sprache und Dogma [above, n. I75], I4I-I66, esp. I 47).

179) See, e.g., c. Iul. imp. 2,88 ("ut sine dono diaboli ad quod dicis libidinem sexuum pertinere nuptiae esse non possent") and c. ep. Pel. I, IO ("dicunt etiam, inquit, motum genitalium et commixtionem coniugum a diabolo fuisse repertam") in context.

180) On some essential changes in his view concerning the presence of sexuality (and even some sinless libido) in Paradise, see, e.g., Émilien Schmitt, Le marriage chrétien dans l'auvre de saint Augustin, (Paris 1983), 85-105; cf. Johannes van Oort, 'Augustine and Mani on Sexual Concupiscence and Original Sin,' Studia Patristica 22, (Leuven 1989), 385 .

181) E.g., Albert Bruckner, Julian von Aeclanum, (Leipzig I 897), 68; Ernesto Buonaiuti, 'The Genesis of St. Augustine's Idea of Original Sin,' Harvard Theological Review Io (I917) I 59I75, esp. I62-I63; idem, 'Manichaeism and Augustine's Idea of "massa perditionis," Harvard Theological Review 20 (I927) I I7-I 27, esp. I 24-I 25; Adam, 'Fortwirken' (see above, 
of Augustine and of the Manichaeans may arise from their sharing the same Jewish-Christian traditions. ${ }^{182}$

Direct Manichaean impulses may be discerned in his biblical exegesis in general $^{183}$ and, for instance, in his anti-Manichaean theory of the fourfold senses of Scripture as it is developed in util. cred. in particular. ${ }^{184}$ Moreover, Augustine's remarkable knowledge of so-called New Testament apocrypha, ${ }^{185}$ as well as his occasional Gospel quotes in accordance with Tatian's Diatessaron, ${ }^{186}$ and, perhaps, even in accordance with the Gospel of Thomas, ${ }^{187}$ seem to be direct fruits from his Manichaean past. The central subject of an exegetical writing such as cons. eu. appears to have been provoked by the Manichaeans' Gospels critique. ${ }^{188}$ The same background seems to have caused Augustine's remarkable emphasis on Scripture's infallibility. ${ }^{189}$ Other theological opinions, too, seem

n. I78), esp. I44-I45; Elizabeth A. Clark, 'Vitiated Seeds and Holy Vessels: Augustine's Manichean Past,' in eadem, Ascetic Piety and Women's Faith. Essays on Late Ancient Christianity, (Lewiston-Queenston I986), 29 I-349, esp. 349 n. 264; Johannes van Oort, 'Augustine and Mani on concupiscentia sexualis' in: J. den Boeft et J. van Oort (eds.), Augustiniana Traiectina. Communications présentées au Colloque International d'Utrecht I3-I4 novembre I986, (Paris I987), I37-I 52.

182) Further on this topic below.

183) E.g., Arthur Allgeier, 'Der Einfluss des Manichäismus auf die exegetische Fragestellung bei Augustin,' in: Martin Grabmann \& Joseph Mausbach (eds.), Aurelius Augustinus, (Köln I930), I-I3.

184) E.g., Hoffmann, Augustins Schrift "De utilitate credendi" (see above, n. 96), I04-I70.

185) Overview in Berthold Altaner, 'Augustin und die neutestamentliche Apokryphen, Sibyllinen und Sextussprüche' (I949), in: idem, Kleine patristische Schriften, hrsg. von G. Glockmann, (Berlin I 967), 204-2 I 5. In this context and with reference to the prominent place of Enoch in the writings of the M. one may recall A.'s striking knowledge of Enochic traditions as well.

186) E.g., Gilles Quispel, 'Mani et la tradition évangélique des judéo-chrétiens' (I972) and idem, 'A Diatessaron Reading in a Latin Manichaean Codex' (I993), in: Johannes van Oort (ed.), Gnostica, Judaica, Catholica. Collected Essays of Gilles Quispel (NHMS 55), (LeidenBoston 2008), 263-269 and 77-82.

187) E.g., Gilles Quispel, 'Saint Augustin et l'Évangile de Thomas' (I974), in: Gnostica, Judaica, Catholica (see above, n. I86), 305-308. Recalling the important place of the prophet Hermes among the M., reference might be made to A.'s remarkable knowledge of Hermetica as well; cf. Johannes van Oort, 'Hermes und Augustinus' (I992), in: Gilles Quispel (ed.), Die Hermetische Gnosis im Lauf der Jahrhunderte, (Haarlem-Birnbach 200o), 29I-3 I6, esp. 303-310.3 I4-3 I6.

188) E.g., Helmut Merkel, Die Widersprüche zwischen den Evangelien, (Tübingen I97I), esp. 226-227.

189) For these and other anti-Manichaean characteristics, see van Oort, Jerusalem and Babylon (see above, n. 37), 39-4I, with reference to Augustinian texts and relevant studies. 
to have become part and parcel of orthodox Western Christianity because of Augustine's anti-Manichaean stance: his underestimation of the cosmic significance of Christ, ${ }^{190}$ and his interpretation of "the groaning of creation" in $\mathrm{Rm}$ 8 as referring to the rational creature, i.e. angels and human beings, only. ${ }^{191}$ The debate with the Manichaean Fortunatus induced Augustine to adopt the concept of "involuntary sin." 192

In evaluating all these and other parallels, ${ }^{193}$ however, one should be aware of the fact that similarity in thought and even terminology can in itself provide no conclusive proof of derivation. Through the discovery of the Cologne Mani Codex the background of Manichaeism in Jewish Christianity has become irrefutably evident. It is this typical Jewish-Christian tradition which, to a considerable extent, was part and parcel of pre-Augustininan Christianity in Roman Africa as well. ${ }^{194}$ From a methodological point of view only those elements which do not occur in the previous Jewish-Christian traditions, but do stand out in both Augustine and Manichaeism, may be specified as testifying to a possible Manichaean influence. ${ }^{195}$ Apart of typical traits in Augustine's view of sexual concupiscence, in his doctrine of the transmission of orginal sin as being caused by the concupiscentia inordinata, in his description of the terrena ciuitas as well as in many features in his biblical interpretation, one may in all likelihood also refer to his typically Christocentric spirituality. ${ }^{196}$ A thorough

190) E.g., Wilhelm Geerlings, 'Der manichäische "Jesus patibilis" in der Theologie Augustins,' Theologische Quartalschrift I 52 (I972) I 24-I 3 I.

191) E.g Thomas E. Clarke, 'St. Augustine and Cosmic Redemption,' Theological Studies I9 (I958) I33-I64; cf. idem, The Eschatological Transformation of the Material World according to Saint Augustine, (Woodstock, Md. I956).

192) Alflatt, 'The Development of the Idea of Involuntary Sin in St. Augustine' (see above, n. I I 3). Cf. for the concept, e.g., retr. I, I 5: "peccatum ... non ... in uoluntate."

193) Apart of those indicated, Adam mentioned several others in his 'Fortwirken' (see above, n. I78) and Dogmengeschichte (see above, n. I75), 255-302, but in most cases his substantiation for their being real Manichaean reminiscences is weak.

194) Van Oort, Jerusalem and Babylon (see above, n. 37), 365-37I.

195) For this methodology, see, e.g., van Oort, ibidem, 222-234.35 I ff. and 'Augustine and Mani on concupiscentia sexualis' (see above, n. I 8I), I49-I 52, in both instances referring to remarkable parallels in preceding common Jewish-Christian tradition.

196) See, e.g., Johannes van Oort, 'Augustin und der Manichäismus,' Zeitschrift für Religionsund Geistesgeschichte 46 (I994) I26-I42, esp. I4I-I42; idem, Mani, Manichaeism and Augustine, (Tbilisi ${ }^{4} 200 \mathrm{I}$ ), 49-51.52-53. One may call to mind the famous heading of Harnack's description of A. in his Dogmengeschichte (see above, n. I74), III, 59: "Die weltgeschichtliche Stellung Augustin's als Reformator der christlichen Frömmigkeit.” 
analysis of what we know through Augustine's own description of his very first writing De pulchro et apto is still a desideratum. ${ }^{197}$

\section{Conclusion}

From his early years onwards, and to the very end of his life, the Manichaean Christians were a real and powerful force for Augustine. Evidently, they were also considered to be a most dangerous force. One will not find in Augustine's oeuvre expressions similar to the very derogatory words, and even invectives, which he time and again uttered in denouncing his former fellow believers. Such wording may be called in question and, moreover, one may doubt the overall fairness of Augustine's representation of the Manichaeans and their doctrines. Here, I may refer to only some conspicious points. Over and over again in his anti-Manichaean oeuvre, Augustine made use of the argument once raised by his friend Nebridius. ${ }^{198}$ But it is evident that he should have been aware of the fact that it was not a really valid argument. According to the Manichaeans, God's very essence was invulnerable, and in all Manichaean texts one finds that they made a distinction between God's very essence and His "members" or aeons of light, which came forth from him, ${ }^{199}$ and part of which according to their gnostic-Christian myth was sent into battle with darkness. Moreover, on many occasions Augustine was simply ridiculing the Manichaeans and their opinions. ${ }^{200}$ Besides, more often than not, their appeal to scriptural texts was not taken seriously, but countered by non-exegetical arguments, ${ }^{201}$ or some reductio ad absurdum. ${ }^{202}$ Augustine's repeated question to the Manichaean doctor Felix "Tell me how many stars there are" ${ }^{203}$ seems

197) Conf. 4,20 ff. indicate that it was permeated with Manichaean trains of thought. A preliminary study: T. Kato, 'Melodia interior. Sur le traité De pulchro et apto,' Revue des Études Augustiniennes I 2 (1966) 229-240.

198) Above, n. I 42. Repeated in, e.g., ord. 2, I7,46; mor. 2,25-26; c. Fort. 7.8.1 6.20.22.28 (six times!); $c$. Fel. I, I9; 2, I.3.7.8.9. I I.I 3.22 (eighth times in the disputation and, at the end, even in Felix' "abjuration”); nat. b. 43; c. Faust. I 3,6; 2 I, I 4; 22,22; c. Sec. 20.

199) See, e.g., ep. Man. frg. sa Feldmann (see above, n. I 2 I) in c. ep. Man. I 3. Cf., e.g., the teaching reported in mor. 2,26 and the description of God from the M.'s Amatorium canticum quoted by A. in $c$. Faust. I 5,5.

200) Many examples in mor. 2, but also in $c$. Faust.

201) E.g., c. Fort.

202) Cf., e.g., van den Berg, Biblical Argument (see above, n. 37), 44 and 70 with reference to $c$. Adim. 24 and 12 resp.

203) C. Fel. I, I 4: "dic mihi quot sunt stellae"; cf. I, , o. 
to be nothing more than an unfair retorical device and does not do justice to their interpretation of a biblical text such as John I 6, I $3 .{ }^{204}$ Modern readers may also be embarrassed when discovering that Augustine's famed dictum "Ego uero euangelio non crederem, nisi me catholicae ecclesiae commoueret auctoritas" is in answer to the Manichaeans' straightforward appeal to "the Gospel," 205 and they surely will feel awkward when learning about Augustine's inquisitional methods as far as the Manichaeans were concerned. ${ }^{206}$ All these facts, in addition to the innumerable testimonies throughout his immense oeuvre, evidence the lifelong and even dreadful challenge the Manichaeans and their haeresis must have presented to Augustine.

Chair Patristics and Gnosticism, Visiting Professor Faculty of Theology/

Faculty of Religious Studies, Radboud University Nijmegen, Netherlands. of Patristics, Faculty of Theology, University of Pretoria, j.van.oort@planet.nl South Africa.
Prof. Dr. J. van Oort

Van Renesselaan 24, $\mathrm{NL}$ - 3703 AH Zeist;

\footnotetext{
204) See, e.g., Kephalaia (ed. Polotsky) I 5,20.

205) C. ep. Man. 5.

206) Cf. apart from haer. 46,9-Io, e.g., ep. 236, I.3.
} 